\title{
Pain Education in the Context of Non-Specific Low Back Pain: The Lived Experience of the Physiotherapist. An Interpretive Phenomenological Analysis
}

\begin{abstract}
Objectives:

The aim of this study was to explore the physiotherapists' lived experiences of providing pain education (PE), to people living with non-specific low back pain (NSLBP). In previous studies, PE has been associated with positive clinical outcomes within the physiotherapeutic management of NSLBP. However, the meaning of providing $\mathrm{PE}$, as experienced by physiotherapists, has not been specifically explored.
\end{abstract}

\section{Methods:}

This study adopted a hermeneutic phenomenological approach to explore PE experiences. Six semi-structured interviews were conducted, interviews were transcribed and analysed in line with the 'interpretative phenomenological analysis' framework.

\section{Findings:}

Five main thematic meaning structures emerged: Experienced significance of assessment in understanding NSLBP, PE as explaining the nature of NSLBP, Experienced challenges in providing PE, Individualisation as key to PE for NSLBP and Reassurance as central to PE for people living with NSLBP.

\section{Conclusions:}

The significance of subjective assessment, was a key component of PE, as experienced by participants. However, differences were noted between participants in addressing the sense of assessment; in seeking a physiotherapeutic understanding of the NSLBP, and in seeking to understand the situation of those who are in pain. Within the participant experience, the significance of 'patient' reassurance was highlighted, related to the individualisation and outcome of PE. Reassurance, as described by participants, was emotive and practically grounded and linked with physical activity promotion. Individualisation in PE, was meaningfully related to language modification and developing positive therapeutic relationships. Physiotherapists described PE particularly challenging related to pain chronicity and psychosocial factors, which may have significant implications to practice. 


\section{INTRODUCTION}

Low back pain is a musculoskeletal condition, experienced by the majority of adults within their lifespan (Balagué, Mannion, Pellisé \& Cedraschi 2012), and acknowledged as the most prominent cause of years lived with disability (Hoy et al., 2010; Global Burden of Disease Collaborators, 2015). In approximately $90 \%$ of people with low back pain, there is no identifiable pathology (Maher, Underwood \& Buchbinder 2017) and thus they are classified as having non-specific low back pain (NSLBP). NSLBP refers to low back pain whereby no specific structural cause can be identified (Sullivan, Hebron \& Vuoskoski 2019) and is associated with significant cost implications worldwide (Whitehurst et al., 2012). NSLBP is precipitated through a complex interrelationship between physical, social, psychological and neurophysiological factors (O'keefe et al., 2015; O'Sullivan et al., 2018) and is reported to have significant emotional, physical and social implications (Maher, Underwood \& Buchbinder 2017). Specifically, people living with NSLBP have described a loss of the sense of self, and withdrawal from social activities (Froud et al., 2014). Clinical guidelines recommend a holistic, "biopsychosocial", approach to the management of NSLBP (National Institute for Health and Care Excellence (NICE), 2016).

The NICE guidelines advocate multimodal care comprising of exercise, manual therapy, behavioural therapies and pain education (PE). A holistic approach is encouraged owing to the absence of long-term positive clinical outcomes associated with single-dimensional therapies (O'Sullivan 2012). For example, exercise and manual therapy, when used in isolation, were shown to have minimal long-term effectiveness in the management of NSLBP (Deyo et al., 2009; Goertz et al., 2012). Thus, a multimodal package of care including exercise therapy, manual therapy, psychological therapies and PE has been advocated. PE includes discussion regarding pain complexity, psychosocial contributing factors and pacing (Traeger et al., 2018). Furthermore, neuroscience PE aims to provide people with a multidimensional understanding of their pain experience by informing people about the biology related to their pain, facilitate empowerment and reconceptualise beliefs (Lochting et al., 2016; Louw et al., 2016). A systematic literature review of randomised control trials has previously highlighted the addition of PE approaches in addition to 'usual' physiotherapy was beneficial in managing pain and disability (Marris et al., 
2019). Although $P E$ is recognised as an important aspect of care in practice settings it provides some challenges related to communication with people living with NSLBP.

As reported in previous studies, physiotherapists have conveyed difficulties communicating with people with NSLBP (Jeffrey \& Foster 2012; Sanders et al., 2013). For example, physiotherapists have expressed reluctance to discuss 'patients' personal life in the context of their pain (Sanders et al., 2013). Additionally, physiotherapists have described communication difficulties when their advice has conflicted with a person's pain beliefs (Jeffrey \& Foster 2012). These challenges may have significant implications to PE practice. However, in depth exploration of the therapist experience regarding PE has not yet been explored in qualitative research. Furthermore, quantitative research often explores PE as an isolated intervention, whereas in reality PE is often integrated throughout the therapeutic encounter over a number of sessions. Therefore, qualitative research exploring the physiotherapist experience of providing PE in the context of NSLBP would provide additional insight into the meaning, intricacies and nuances of its use in clinical practice. Qualitative research is thought to be helpful in exploring personal meaning and context in the clinical setting, particularly in pain related topics (Wideman, Hudon \& Bostick 2018). Therefore, the current study aimed to explore the physiotherapists' lived experiences of providing PE to people living with NSLBP.

\section{METHODOLOGY}

\subsection{Study Design}

Ethical approval was obtained through a University ethics committee in the South of England. This study adopted a qualitative, hermeneutic phenomenological approach. This facilitated detailed exploration of the sense of providing PE in the context of managing NSLBP, as lived meaningful by physiotherapists. Phenomenology provides a true essence of lifeworld experiences whilst not presupposing knowledge of such experiences (Converse 2012; Petty, Thomson \& Stew 2012). Hermeneutic phenomenological methodology was implemented owing to its efficiency when exploring individual variation and particularities of lived experiences (Giorgi, 2009; Smith, Flowers \& Larkin 2009). 


\subsection{Participants and Recruitment}

Six physiotherapists who identified themselves as using PE in their practice were purposefully recruited as participants of the research study. Physiotherapy clinics were contacted to enquire if physiotherapists would like to participate in the study. All participants provided informed consent prior to their participation. A minimum of three participants have previously been advocated to provide high quality, rich and varied descriptions in phenomenological research (Giorgi, 2009; Wertz et al., 2011). Furthermore, all authors agreed that sufficient depth had been achieved with the six interviews, therefore additional interviews were not required. Data saturation refers to the point at which further emergent themes will not be identified with further data collection (Saunders et al., 2018). Data saturation was not achieved in the current study as in phenomenological research additional meanings can always be explored (Van Manen, Higgins \& van der Riet 2016).

Inclusion criteria demanded that the participants were currently working within musculoskeletal physiotherapy contexts and had experiences of providing PE for people with NSLBP within six-months prior to interview. This ensured participants' ability to discuss, in detail, their concrete lived-through experiences of the phenomenon of interest. To ensure richness and variation in the experience, participants were recruited via two private physiotherapy clinics. In this article, pseudonyms have been used to protect participant anonymity (see Table 1 for participant characteristics).

\subsection{Interviews}

Each physiotherapist participated in one individual, face-to-face interview with the first author (JW). Semi-structured interviews were conducted to encourage participants to discuss their experiences, in depth, freely and reflectively. An interview schedule adopted from the format of Smith et al. (2009) was used to facilitate both, structure and specificity throughout the interviews (Figure 1). Interviews commenced with an open question, "Can you put into words your experience of providing pain education with patients with non-specific low back pain?" As advocated by Kvale and Brinkman (1996), probing questions were utilised to encourage depth of description regarding 
their experiences of providing PE, without leading or biasing the data. Such probing questions included "You mentioned...can you tell me more about that?" Interviews averaged 45 minutes in duration. All interviews were audio-recorded and transcribed verbatim by the same researcher-interviewer.

Figure 1. Interview Schedule:

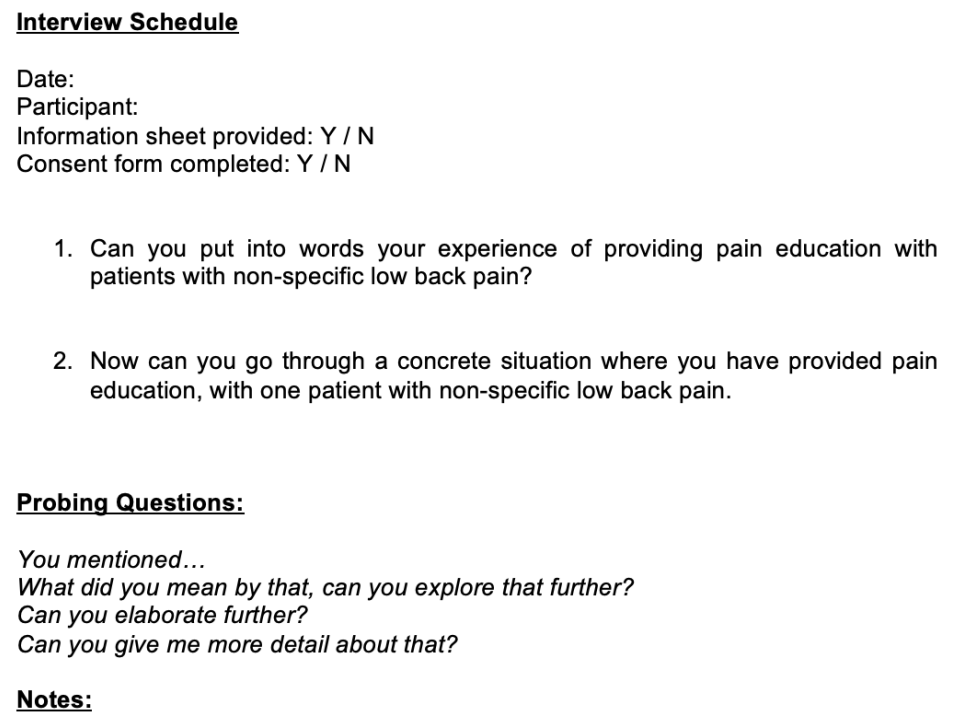

\subsection{Data-Analysis}

The process of data handling and analysis, in this study, followed the steps of interpretative phenomenological analysis (IPA), by Smith et al. (2009). The dataanalysis was initially completed by the $1^{\text {st }}$ author (JW) in close supervision and collaboration with the $4^{\text {th }}$ author (PV), and later reviewed by the $2^{\text {nd }}(\mathrm{LM})$ and $3^{\text {rd }}$ author $(\mathrm{CH})$. Hence, the findings and their implications are based on critical peer-review, as well as shared understanding and consensus reached within the research team.

Data-analysis was completed in the following steps:

1. Simultaneously reading and listening to the audio recording of each interview. This facilitated active engagement with the data and supported the researcher to gather a sense of the 'whole.' During this process, the researcher recorded 
personal, prevailing observations of the transcript, improving awareness of any pre-assumptions which may have impaired transparency during data-analysis.

2. Dividing each transcript into 'meaning units' ('parts' of the text containing a meaning), followed by initial noting; that is, highlighting descriptive, linguistic and conceptual comments identified with the meaning units. Reflection on these notes formulated emergent themes for each participant (Appendix 1). This served to reduce the volume of data whilst representing interrelationships and patterns.

3. Super-ordinate themes were then identified by searching for connections across emergent themes and subsequently grouping them (Appendix 2 ).

4. This rigorous process was repeated for each participant account, prior to searching for patterns across participants. Super-ordinate themes were then analysed, extrapolating similarities and differences to formulate final master themes (appendix 3), showing connections for the participant group as a whole.

Principles of the hermeneutic circle were closely considered throughout the entire process. This facilitates a continuous, dynamic relationship between the 'parts' and 'whole' of the data, the researchers' and participants' interpretations, and the new understandings obtained through the cyclical research process (Smith et al., 2009). This enhanced in-depth interpretation and understanding of the participants' lifeworld, and the sense of PE as lived meaningful by physiotherapists through continual reexamination of propositions (Rapport \& Wainwright 2006).

\subsection{Methodological Rigour}

Methodological rigour and trustworthiness were enhanced through an "independent audit", a process described by Smith et al. (2009). This process required the recording of each step of data-analysis to demonstrate the coherent and thorough research approach (Appendix 1,2,3). In addition, the $1^{\text {st }}$ author (JW) kept a reflexive diary throughout the research process to record his own understandings, pre-assumptions 
and thoughts which may have implications to the data-analysis. This facilitated a transparent approach to the data analysis through repetitive consideration of personal experiences and beliefs.

\section{FINDINGS}

Table 1 describes the characteristics of the six participants who participated in the study.

\begin{tabular}{|c|c|c|c|c|c|}
\hline $\begin{array}{c}\text { Participant } \\
\text { Name }\end{array}$ & Gender & $\begin{array}{c}\text { Current Nature } \\
\text { of Work }\end{array}$ & $\begin{array}{c}\text { Years } \\
\text { Worked } \\
\text { in Private } \\
\text { Practice }\end{array}$ & $\begin{array}{c}\text { Length of } \\
\text { Time in } \\
\text { Previous NHS } \\
\text { Employment } \\
\text { (Years) }\end{array}$ & $\begin{array}{c}\text { Level } \\
\text { when } \\
\text { working } \\
\text { in NHS }\end{array}$ \\
\hline Linda & Female & $\begin{array}{c}\text { Musculoskeletal } \\
\text { (private practice) }\end{array}$ & 7 & 6 & Band 6 \\
\hline Paula & Female & $\begin{array}{c}\text { Musculoskeletal } \\
\text { (private practice) }\end{array}$ & 21 & 20 & Band 7 \\
\hline Jessica & Female & $\begin{array}{c}\text { Musculoskeletal } \\
\text { (private practice) }\end{array}$ & 15 & 23 & Band 7 \\
\hline Sophie & Female & $\begin{array}{c}\text { Musculoskeletal } \\
\text { (private practice) }\end{array}$ & 11 & 14 & Band 7 \\
\hline Bethan & Female & $\begin{array}{c}\text { Musculoskeletal } \\
\text { (private practice) }\end{array}$ & 30 & 21 & Band 5 \\
\hline Rachel & Female & $\begin{array}{c}\text { Musculoskeletal } \\
\text { (private practice) }\end{array}$ & 2 & 7 & Band 6 \\
\hline
\end{tabular}

Table 1. Participant characteristics

*Band 5 - Junior Physiotherapist, Band 6 - Senior Physiotherapist, Band 7 - Clinical specialist/team lead.

Following the data-analysis, five master themes were identified and are displayed in

Figure 2. Interrelatedness exists between all themes and will be discussed using participant quotes. 
Figure 2. Master Themes:

\begin{tabular}{|l|l|}
\hline Theme 1 & $\begin{array}{l}\text { Experienced significance of assessment in } \\
\text { understanding NSLBP }\end{array}$ \\
\hline Theme 2 & Pain education as explaining the nature of NSLBP \\
\hline Theme 3 & Experienced challenges in providing PE \\
\hline Theme 4 & Individualisation as key to PE for NSLBP \\
\hline Theme 5 & $\begin{array}{l}\text { Reassurance as central to PE for people living with } \\
\text { NSLBP }\end{array}$ \\
\hline
\end{tabular}

\subsection{Experienced Significance of Assessment in Understanding NSLBP}

The experienced significance of subjective assessment in understanding the nature of NSLBP, was a deep-rooted theme across participants. Participants highlighted the significance of assessment in understanding the nature and implications of pain as well as the situation of the person who is in pain. However, there was variation in how participants made sense of the significance and what perspectives to assessment they highlighted. For example, Linda and Paula, although in slightly different words, both highlighted the significance of subjective assessment, from the perspective of the physiotherapist:

"...I would go through your normal, sort of subjective assessment and there I would be working out if there were any sort of yellow flags or issues...that may be impacting their pain...l'd be sort of picking up any indication as to whether, that I guess if things would be impacting their pain or pain situation."

(Linda)

“...the subjective was really important because you could see, you could see his worries... He had also recently changed jobs and had some issues at home I think as well. So, there was a whole heap of other stuff going on as well. And of course, with back pain, we tend to look at if there is other things going on in their lives as well. And whether there is other stresses." 
Rachel, in turn, addressed the significance of herself (as a physiotherapist) asking questions and using methods that would help the person (who is in pain) themselves to understand their pain and situation with it:

“... ask them loads of questions about their lifestyle...Then I videoed him as well, looked um, showed him how he was moving, and he could see that his back wasn't in a good position when he was squatting. And that gave him that kind of feedback, he could see it, so when he could see it, he was like aw ok, I can see what's happening now."

(Rachel)

Sophie also explicitly addressed the significance of helping the person themselves to understand the meaning of their pain.

"But this was really key for him finding out for himself...so, explaining to him in his case that his injury will have long healed, but he would have been left with the results of the injury such as scar tissue maybe um tight, tight muscles, immobile joints and so on...And then showing him how his adaptive behaviour was what was making him worse rather than the um, the original injury that happened in the first place."

(Sophie)

Overall, the experienced significance of assessment and understanding the nature of the NSLBP was present in all participant descriptions, but in a qualitatively different sense. There is a qualitatively significant difference between addressing one's understanding of the pain and situation of another person, and addressing the understanding of one's own situation and pain; the former addressing the perspective of the 'therapist' and the latter the perspective of the 'patient'.

\subsection{PE as Explaining the Nature of NSLBP}

The experienced significance of PE as explaining the nature of NSLBP was meaningfully present throughout the data. All participants highlighted the significance of being able to explain the rationale of the contributing pain factors to their 'patients'. 
However, the sense of the experienced significance again varied between participants. For example, Bethan and Rachel, both explicitly addressed the significance of explaining the rationale behind the potential causes of pain for the 'patient', in helping the understanding of their 'patient':

“...you're stiff there and it's a bit tight over there...your back is a bit tight. You know the muscles are a bit tight and therefore, it's quite normal for you to actually feel it a bit...it's people understanding that actually why have they got, you know why have they got pain."

(Bethan)

“...they've got a stiff back, if they've got muscle weakness, muscle tightness. And then I'll say all of those things can be a possible source of pain...pick something up and you're moving just through your back and not from your hips and your knees where you should be moving then you're loading the back...you're doing nothing, you're not stretching, you're not strengthening, you're not moving, you're not servicing your body. And that all adds up to kind of pain and you know whatever structure I think potentially is at fault."

(Rachel)

Bethan and Rachel, thus, addressed the significance of explaining potential causes of NSLBP, by focusing on mechanical factors and 'structures', to help people understand their pain. Moreover, Rachel's description conveyed a sense of blame towards the person living with NSLBP, addressing their actions as directly contributing pain factors. This contrasts with Sophie's description, who related pain explanations to wider, experiential aspects, and helping people to understand the meaning and inter-related nature of their pain, in a somewhat wider sense.

"Explaining to people how when they're stressed, when their anxious and so on that can make things worse...because someone's in low mood, they will do less, cus they're doing less, they get weakness, they then have got weakness, that will in turn then effect the pain... when you're stressed it will, it's like turning up an amplifier, up the volume, it can make your pain worse." 
Thus, this theme highlighted the experienced significance of explaining the rationale of pain for the person living with NSLBP (as experienced by therapists). However, there was variation again in how participants related the sense of their experience, which may have significant implications to PE practice. There is a qualitatively significant difference between addressing 'patient responsibility' and 'blaming the patient'; the former suggesting a more positively related sense and the latter a more negatively related sense of understanding.

\subsection{Experienced Challenges in Providing PE}

All participants described situations of PE that they experienced challenging, in providing PE related to NSLBP. However, the contextual relatedness of such challenges varied between participants. Linda and Jessica, for example, expressed $\mathrm{PE}$ to be particularly challenging when providing $\mathrm{PE}$ to people living with chronic NSLBP.

"...It is much harder when they have had issues going on for a long time...Somebody who's been in pain for 10 years and they've seen I don't know five chiropractors and several physios and several doctors who have told them different things...it's quite difficult then because why are you different from any of those other people they have seen...it is really hard."

(Linda)

"That's often the story with chronic people that you end up, you know they're so depressed and low that you feel a bit like the Dementors in Harry Potter, you feel like your soul is being sucked out of you because you're constantly trying to kind of buffer them up...So you've got chronic problems and they're depressed...they can't play golf, they can't do their shopping, they can't drive very far, they're not working...you cry with people sometimes, it's tough....with him I did get a bit frustrated... he seemed a bit needy."

(Jessica)

Thus, the challenges for Linda and Jessica, were meaningfully related to providing PE for people with chronic pain, who may have previously experienced several 
unsuccessful treatments. Bethan, in turn, addressed the challenge of exploring the beliefs of pain in people living with NSLBP.

“...people aren't going to know what they believe about their pain...it's not easy to kind of come out and say, well what do you believe about your pain?"

(Bethan)

Collectively, participants addressed experienced challenges related to PE in varying situations. A qualitatively significant commonality between participants, nevertheless, highlights the experienced challenges in providing PE, which may have significant implications to practice.

\subsection{Individualisation as Key to PE for NSLBP}

All participants more or less explicitly addressed the experienced significance of individualisation in PE. Again, the sense and relatedness of individualisation varied between participants. For Jessica, for example, individualisation related to linguistic modification; use of analogies in explaining the rationale of pain, utilised on an individualised-basis.

"I often use the analogy of a car that say has got an oil light on the dashboard. You take it to the garage and you get it all looked at, the mechanic at the garage makes sure that everything is fine...you bring it home and the oil light is still on...you know pain is being maintained by a centralised system rather than a problem with the joints, or the ligaments...I don't think I used the oil light analogy with him because I think, he had never had back pain before."

(Jessica)

For Bethan, the sense of individualisation related to the building of sound therapeutic relationships, and a personalised approach to PE. Bethan explicitly addressed teamwork and honesty as routes to building trust and rapport with the person in pain. 
“...you've got to see them as individuals. And really what is needed as an individual...l'm trying to be honest with them, they need to be honest with me...part of teamwork...you've got to have a little bit of rapport... They have to trust you, and that doesn't come overnight. And it doesn't come by just doing the physical...you've got to have a relationship."

(Bethan)

The significance of individualisation for Bethan thus related to viewing 'patients' as 'individuals' and adopting an interpersonal approach as meaningful to PE. Whereas, for Jessica, the significance of individualisation per se perhaps was less explicitly present, and related to her (the therapist) choice of language in communicating with the person in pain (the 'patient'). Hence, the variation again in how participants related the sense of 'individualisation' may have significant implications to PE practice.

\subsection{Reassurance as Central to PE for People Living with NSLBP}

'Patient' reassurance as a significant part of PE was meaningfully present throughout the participant descriptions, although in a somewhat varied sense. For example, Paula explicitly addressed the essential role of 'patient' reassurance in providing PE:

“...my pain management was all about reassurance...Reassurance that there is nothing sinister, which I think is what they're after...I held her hand and I promised her she would be alright...mostly it's just reassurance."

(Paula)

Jessica, in her account, similarly addressed the significance of 'patient' reassurance. For Jessica, however, reassurance as a key element of PE, is ultimately linked to encouragement for physical activity.

"...you can then reassure them really well...the signs are that there is nothing seriously wrong... what I did with him, was just reassure him that nothing serious was wrong. And that as long as he was willing to move and you know try and get back to a normal pattern at work he would be absolutely fine...Y You know 
your joints need movement, muscles need movement...getting him to understand that movement was harmless and it would be good."

(Jessica)

In summary, although all participants addressed the significance of 'patient' reassurance in providing PE, meaningful differences were identified across participant experiences. For example, there is a qualitatively significant difference in addressing 'patient' reassurance as such, and addressing reassurance as the means for encouraging physical activity.

\section{DISCUSSION}

This study was undertaken to explore, in what way providing PE is experientially meaningful to physiotherapists when related to the physiotherapy management of NSLBP. Based on the interpretive phenomenological analysis, five master themes emerged from the empirical data: Experienced significance of assessment in understanding NSLBP, PE as explaining the nature of NSLBP, Experienced challenges in providing PE, Individualisation as key to PE for NSLBP and Reassurance as central to PE for people living with NSLBP. These themes are interrelated and indicate the qualitative significance of certain key meanings which stood out in the participant descriptions. These themes will now be discussed together with relevant research.

In this study, the meaning of providing PE to people living with NSLBP was examined from the perspective of the physiotherapist. The findings highlighted the experienced significance of subjective assessment in PE. The participants particularly highlighted the significance of assessment related to understanding and explaining the nature of NSLBP. However, a qualitatively significant contrast was evidenced between participants who emphasised assessment as a route to their own understanding of their 'patient's' pain, and those who highlighted the experienced significance of assessment in helping the 'patient' to understand their own pain, and situation of living with the NSLBP. In addition, participants described experiences of challenging 
situations in PE related to physiotherapeutic management of people with chronic NSLBP, and attempts to explore pain beliefs in those living with pain.

Similar issues have been previously discussed in other papers. Wijma et al. (2016), for example, describes the importance of the assessment process to explore biopsychosocial pain contributing factors to subsequently 'tailor education' to individualise the management approach for people with chronic pain. Holopainen et al. (2018), in their phenomenographic paper, discussed the conceptions of 'patients' with NSLBP about their encounters in health care system. Participants valued a shared understanding of their pain and a strong therapeutic relationship to facilitate an active role in their own rehabilitation. These discussions all highlight the significance of understanding the phenomenon of pain as well as the individual in pain, although from varying perspectives to PE.

Collectively, the participants highlighted challenging situations in PE, particularly when working with people living with chronic NSLBP. In addition, some of the participants described doubting their own skills as a physiotherapist, in exploring the meaning of the pain for the person living with NSLBP. This resonates with the findings of a metasynthesis where physiotherapists described working with people living with NSLBP particularly challenging when psychosocial factors predominate (Synnott et al., 2015). Physiotherapists have previously been reported to describe the profession as 'standing on thin ice' when exploring the psychosocial factors associated with pain (Singla et al., 2015). Moreover, in previous studies, physiotherapists described feelings of incapability in providing PE, for people with NSLBP, due to minimal training (Synnott et al., 2016). These findings suggest wide-reaching implications for the physiotherapy profession and practice, and as such need further exploration in the future.

Individualisation of PE was central to participant experiences, although the sense and relatedness of their experience varied. Participants addressed language modification; such as the use of analogies, as a means to individualisation and positive clinical outcomes. This resonates with existing research suggesting that individualisation of 'patient' care influences outcomes patient-therapist interactions (O'Keefe et al., 2016). Furthermore, the modification of communication facilitates understanding, PE 
effectiveness and 'patient' satisfaction (Laerum, Indahl \& Skouen 2006). Individualisation of PE was also positively linked with therapeutic relationships, in the current analysis. The significance of the therapeutic relationship, as described by participants, related to building rapport and viewing the person as an 'individual'. In previous studies, therapeutic relationship has been positively linked with patientcentred communication (Pinto et al., 2012), therapist interpersonal skills (Fuentes et al., 2014), and treatment adherence (Ferreira et al., 2013). Overall, the findings of this study are harmonious with previous studies.

The participants of this study highlighted the experienced significance of 'patient' reassurance in $\mathrm{PE}$, positively related with therapeutic outcomes and therapeutic relationship. This parallels with guidelines advocating reassurance techniques in the management of NSLBP, addressing that reassurance may reduce fear and negative health beliefs, which can both negatively impact NSLBP (Koes et al., 2010). In the current study, the significance of reassurance was meaningfully related to consideration of symptom severity and diagnosis of NSLBP, and participants aimed to encourage improved outlook on their patient's prognosis. Participants also described using non-verbal communication, presented through hand-holding during the reassurance process. This resonates with research highlighting touch as a method of communicating empathy within physiotherapy (Bjorbaekmo \& Mengshoel 2016) and thus, may reflect an emotive approach. Aligning with this, Holt and Pincus (2016) found people with NSLBP to value emotionally-reassuring physiotherapist behaviours (verbal and non-verbal).

Current findings suggest that $\mathrm{PE}$, through reassuring individuals in pain, as experienced by participants, can be perceived to be central to encouraging people's physical activity. Moreover, Jessica particularly addressed patient reassurance as a key element of PE, ultimately linked to encouragement for physical activity. The importance of reassurance has been noted in recent literature which established that reassuring people with NSLBP to engage in exercise, as part of PE, encourages autonomic agency and pro-active recovery (Holopainen et al., 2018). As highlighted in another study, a focus on reassurance as part of PE may also have further implication for healthcare costs (Traeger et al., 2015). However, despite current and existing findings highlighting reassurance-focused PE, literature lacks guidance on 
implementation methods. Therefore, further research that explores the use of reassurance in $\mathrm{PE}$ is required.

\subsection{Limitations}

This study aimed to produce phenomenological, interpretive knowledge and new insights into PE experiences, by means of detailed exploration of subjective accounts related to physiotherapy management of NSLBP. Therefore, the current study, as an example of a context-limited study, provides knowledge which has applicability to context-similar situations only. More specifically, participants in this study worked solely within private practice in the UK. Understanding PE experiences within the NHS, in addition to privately-based experiences, would provide further insight into PE for NSLBP. People living with NSLBP potentially may have more frequent, and longer duration, physiotherapy appointments when seen in the private sector in comparison to the NHS. Furthermore, participant demographic variation e.g. with regard to gender, level of clinical experience and postgraduate training may present disparate findings whilst contributing to depth and richness of future research data as well as understanding the phenomenon. Finally, the primary researcher had professional PE experience with people with NSLBP; potentially creating a researcher bias. However, a reflexive diary was maintained, and a shared consensus was pursued within the research team, to help acknowledgement of pre-conceptions throughout the process.

\subsection{Implications for Practice}

It is the claim of this study that a more clarified understanding of physiotherapists' PE experiences related to physiotherapy management of NSLBP, could serve the physiotherapy community and practice in many valuable ways. Owing to the phenomenological approach, the aim was not to present generalisable findings; rather, the authors hope to encourage critical reflection of practice. Significant implications were identified on the basis of the presented evidence and identified key meaning structures in this study. Firstly, all participants highlighted the significance of assessment in understanding NSLBP. However, a qualitatively significant difference was noted between addressing the sense of assessment in seeking the physiotherapists' understanding of pain, and in seeking the understanding of those 
who are in pain; the former addressing the significance of the therapist and the latter addressing the significance of the 'patient'. Perhaps, in practice, adopting a personcentred approach to evidence-based pain management, which considers the meaning of both should be equally addressed.

Secondly, explaining the complex nature of NSLBP was experienced as a key element of PE. However, as evidenced in the data, this process varied between participants. There is a qualitatively significant difference between addressing the complex nature of pain to aid 'patient' understanding (non-blaming approach) and 'blame' (blaming approach). The former suggests a positively related role for the person in pain, and the importance of understanding the inter-related nature of pain. In contrast, the latter infers 'blame' on the 'patient' in a more negatively related sense (being responsible for the existence of their pain). This again may have further ethical implications; therefore, clinicians must be mindful in their approach to explaining pain. Incorporating ethical considerations, however, may be useful to facilitate a PE practice more attuned to a 'non-blaming' approach than catastrophising and negative beliefs.

Individualisation in PE was more or less explicitly addressed by all participants in this study. Yet the sense and relatedness of individualisation varied between participants. The variation may have significant implications to PE practice. Thus, physiotherapists should be mindful of how they understand and apply 'individualisation' in their practice, as it may serve as a route to encouraging 'patient' engagement and adherence to selfmanagement.

Finally, 'patient' reassurance was highlighted meaningful in PE, positively related with therapeutic outcomes, therapeutic relationships, and adopting emotive and/or practical perspectives. This resonates with current research and guidelines advocating reassurance techniques as well as research highlighting emotionally-reassuring physiotherapist behaviours. Therefore, physiotherapists could work to reassure individuals with NSLBP through PE that is both practically based and emotive.

Current findings have highlighted potential research development areas regarding PE for NSLBP which could explore: 
- How physiotherapists help individuals to understand the meaning of their own pain.

- Physiotherapists' perceptions and experiences of managing psychosocial aspects of NSLBP.

- Exploring physiotherapists' perceived barriers to providing PE for NSLBP and how the profession can overcome these.

- The variation of PE for NSLBP within different physiotherapy settings.

\section{CONCLUSION}

This phenomenological study explored the physiotherapists' lived experience of providing PE, to people living with NSLBP. All six participants of this study indicated the experienced significance of subjective assessment, in understanding the nature of the NSLBP for each person in pain, and/or facilitating the person themselves to understand the mechanisms of their pain. The participants addressed the relatedness of the assessment outcomes and their explanations of the nature of NSLBP to those in pain. Such explanations were linked to individualisation and were meaningfully supported through the therapeutic relationship, and building of rapport. Finally, the significance of 'patient' reassurance in PE, was highlighted and linked with encouragement of physical activity. Participants also described challenges in PE, related to physiotherapeutic management of people with chronic NSLBP, and their beliefs of pain. It is hoped that this study may serve to prompt critical reflection of practice to support future experiences of PE in the context of NSLBP. This may include physiotherapists considering a shared understanding of NSLBP education, addressing the significance of physiotherapy assessment within a non-blaming, individualised, emotive and practical approach. 


\section{Reference List}

Balagué, F., A.F. Mannion, F. Pellisé, and C. Cedraschi. (2012). Non-specific low back pain. The Lancet 379(9814): 482-491.

Bjorbaekmo, W.S., \& Mengshoel, A.M. (2016). "A touch of physiotherapy' - the significance and meaning of touch in the practice of physiotherapy. Physiotherapy Theory and Pracice, 32 (1): 10-19.

Converse, M. (2012). Philosophy of phenomenology: How understanding aids research. Nurse researcher, 20 (1): 28-32.

Deyo, R.A., S.K. Mirza, J.A. Turner, and B.I. Martin. (2009). Overtreating chronic back pain: Time to back off? Journal of the American Board of Family Medicine : JABFM, 22 (1): 62-68.

Ferreira, P.H., Ferreira, M.L., Maher, C.G., Refshauge, K.M., Latimer, J., \& Rogers, A. (2013). The therapeautic alliance between clinicians and patients predicts outcome in chronic low back pain. Physical Therapy, 93 (4) 470-478.

Froud, R., S. Patterson, S. Eldridge, C. Seale, T. Pincus, D. Rajendran, C. Fossum, and M. Underwood. (2014). A systematic review and meta-synthesis of the impact of low back pain on people's lives. BMC musculoskeletal disorders, 15 (50) 1-5.

Fuentes, J., Armijo-Olivo, S., Funabashi, M., Miciak, M., Dick, B., Warren, S., Rashiq, S., Magee, D.J., \& Gross, D.P. (2014). Enhanced therapeutic alliance modulates pain intensity and muscle pain sensitivity in patients with chronic low back pain: An experimental controlled study. Physical therapy, 94 (4): 477-489.

Giorgi, A. (2009). The descriptive phenomenological method in psychology A modified husserlian approach. Michigan: Duquesne University Press.

Global Burden of Disease Collaborators. (2015). Global, regional, and national incidence, prevalence, and years lived with disability for 301 acute and chronic diseases and injuries in 188 countries, 1990-2013: A systematic analysis for the global burden of disease study 2013. The Lancet 386 (9995): 743-800.

Goertz, C.M., K.A. Pohlman, R.D. Vining, J.W. Brantingham, and C.R. Long. (2012). Patient-centered outcomes of high-velocity, low-amplitude spinal manipulation for low back pain: A systematic review. Journal of electromyography and kinesiology : official journal of the International Society of Electrophysiological Kinesiology, 22 (5): 670673.

Holopainen, R.A., Piirainen, A., Heinonen, A., Karppinen, J., \& O'Sullivan, P. (2018). From "Non-encounters" To autonomic agency. Conceptions of patients with low back pain about their encounters in the health care system. Musculoskeletal care, 15 (1): 10-20. 
Holt, N., \& Pincus, T. (2016). Developing and testing a measure of consultation-based reassurance for people with low back pain in primary care: A cross-sectional study. BMC musculoskeletal disorders, 17 (1): 277-285.

Hoy, D., L. March, P. Brooks, A. Woolf, F. Blyth, T. Vos, and R. Buchbinder. (2010). Measuring the global burden of low back pain. Best Practice \& Research Clinical Rheumatology 24 (2): 155-165.

Jeffrey, J.E., and Foster, N.E. (2012). A qualitative investigation of physical therapists' experiences and feelings of managing patients with nonspecific low back pain. Physical Therapy, 92 (2): 266-278.

Koes, B.W., Van Tulder, M.W., Lin, C.W., Macedo, L.G., McAuley, J., \& Maher, C. (2010). An updated overview of clinical guidelines for the management of non-specific low back pain in primary care. European Spine Journal, 19 (12): 2075-2094.

Kvale, S. \& Brinkman, S. (1996). Interviews: An introduction to qualitative research interviewing. London: Thousand Oaks.

Laerum, E., Indahl, A., \& Skouen, J.S. (2006). What is "The good back-consultation"? A combined qualitative and quantitative study of chronic low back pain patients' interaction with and perceptions of consultations with specialists. Journal of rehabilitation medicine, 38 (4): 255-262.

Lochting, I., Storheim, K., Werner, E.L., Småstuen Cvancarova, M., \& Grotle, M. (2016). Evaluation of individualized quality of life and illness perceptions in low back pain. A patient education cluster randomized controlled trial. Patient Education and Counseling, 99 (12): 1992-1998.

Louw, A., Zimney, K., Puentedura, E.J., \& Diener, L. (2016). The efficacy of pain neuroscience education on musculoskeletal pain: A systematic review of the literature. Physiotherapy theory and practice, 32 (5): 332-355.

Maher, C., M. Underwood, and R. Buchbinder. (2017). Non-specific low back pain. The Lancet, 389 (10070): 736-747.

Marris, D., Theophanous, K., Cabezon, P., Dunlap, Z., \& Donaldson, M. (2019). The impact of combining pain education strategies with physical therapy intrerventions for patients with chronic pain: A systematic review and meta-analysis of randomized controlled trials. Physiotherapy theory and practice, 1-12.

National Institute for Health and Care Excellence. (2016). Low back pain and sciatica in over 16s: Assessment and management. [Online] NICE. Available from: https://www.nice.org.uk/guidance/NG59 [11 February 2017].

O'Keefe, M., H. Purtill, N. Kennedy, P. O'Sullivan, W. Dankaerts, A. Tighe, L. Allworthy, L. Dolan, N. Bargary, and K. O'Sullivan. (2015). Individualised cognitive functional therapy compared with a combined exercise and pain education class for 
patients with non-specific chronic low back pain: Study protocol for a multicentre randomised controlled trial. BMJ open, 5 (6): 1-10.

O’Keffe, M., Cullinane, P., Hurley, J., Leahy, L., Bunzli, S., O'Sullivan, K. (2016). What influences patient-therapist interactions in musculoskeletal physical therapy? Physical Therapy, 96 (5), 609-622.

O'Sullivan, P. (2012). It's time for change with the management of non-specific chronic low back pain. British journal of sports medicine, 46 (4): 224-227.

O'Sullivan, P.B., J.P. Caneiro, M. O'Keeffe M, A. Smith, W. Dankaerts, K. Fersum and K. O'Sullivan. (2018). Cognitive functional therapy: an integrated behavioral approach for the targeted management of disabling low back pain. Physical Therapy, 98 (1):408423.

Petty, N., Thomson, O.P., \& Stew, G. (2012). Ready for a paradigm shift? Part 2: Introducing qualitative research methodologies and methods. Manual therapy, 17 (5) 378-384.

Pinto, R.Z., Ferreira, M.L., Oliveira, V.C., Franco, M.R., Adams, R., Maher, C.G., \& Ferreira, P.H. (2012). Patient-centred communication is associated with positive therapeutic alliance: A systematic review. Journal of physiotherapy, 58 (2): 77-87.

Rapport, F., \& Wainwright, P. (2006). Phenomenology as a paradigm of movement. Nursing Inquiry, 13 (3): 228-236.

Sanders, T., Foster, N.E., Bishop, A., \& Ong, B.N. (2013). Biopsychosocial care and the physiotherapy encounter: physiotherapists' accounts of back pain consultations. BMC Musculoskeletal Disorders, 14 (65): 1-10.

Saunders, B., Sim, J., Kingstone, T., Baker, S., Waterfield, J., Bartlam, B., Burroughs, H., \& Jinks, C. (2018). Saturation in qualitative research: exploring its conceptualization and opertionalization. Quality and Quantity, 52 (4): 1893-1907.

Singla, M., Jones, M., Edwards, L., \& Kumar, S. (2015). Physiotherapists' assessment of patients' psychosocial status: Are we standing on thin ice? A qualitative descriptive study. Manual Therapy, 20 (2): 328-334.

Smith, J.A., Flowers, P., \& Larkin, M.H. (2009). Interpretative phenomenological analysis: Theory, method and research. London: SAGE.

Sullivan, N., Hebron, C., and Vuoskoski., P. (2019). "Selling chronic pain: physiotherapist' lived experiences of communicating the diagnosis of chronic nonspecifc lower back pain to their patients. Physiotherapy Theory and Practice, 120.

Synnott, A., O'Keeffe, M., Bunzli, S., Dankaerts, W., O'Sullivan, P., \& O'Sullivan, K. (2015). Physiotherapists may stigmatise or feel unprepared to treat people with low 
back pain and psychosocial factors that influence recovery: A systematic review. Journal of physiotherapy, 61 (2): 68-76.

Synnott, A., O'Keeffe, M., Bunzli, S., Dankaerts, A., O'Sullivan, P., Robinson, K., \& O'Sullivan, K. (2016). Physiotherapists report improved understanding of and attitude toward the cognitive, psychological and social dimensions of chronic low back pain after cognitive functional therapy training: A qualitative study. Journal of physiotherapy, 62 (4): 215-221.

Traeger, A.C., Hübscher, M., Henschke, N., Moseley, G.L., Lee, H., \& McAuley, J.H. (2015). Effect of primary care-based education on reassurance in patients with acute low back pain: Systematic review and meta-analysis. JAMA internal medicine, 175 (5): 733-740.

Traeger, A., Lee, H., Hubscher, M., Skinner, I.W., Moseley, L., Nicholas, M.K., Henschke, N., Refshauge, M., Blyth, F.M., Main, C.J., Hush, J.M., Lo, S., \& McAuley, J.H. (2019). Effect of intensive patient education vs placebo patient education on outcomes in patients with acute low back pain a randomised clinical trial. JAMA Neurology, 76 (2), 161-169.

Van Manen, M., Higgins, L., \& van der Riet, P. (2016). A conversation with Max van Manen on phenomenolgoy in its original sense. Nursing \& Health Sciences, 18 (1): 47.

Wertz, F., Charmaz, K., McMullen, L., Josselson, R., Anderson, R., McSpadden, E. (2011). Five ways of doing qualitative analysis: Phenomenological psychology, grounded theory, discourse analysis, narrative research and intuitive inquiry. Guildford Press, New York.

Whitehurst, D., Stirling, B., Lewis, M., Hill, J., Hay, E. (2012). Exploring the cost-utility of stratified primary care management for low back pain compared with current best practice within risk-defined subgroups. Clinical and epidemiological research, 71 (11), 1796-1802.

Wideman, T.H., Hudon, A., \& Bostick, G. (2018). The added value of qualitative methodologies for studying emotional disclosure about pain. American pain society, 1.

Wijma, A.J., Van Wilgen, C.P., Meeus, M., \& Nijs, J. (2016). Clinical biopsychosocial physiotherapy assessment of patients with chronic pain: The first step in pain neuroscience education. Physiotherapy theory and practice, 32 (5): 368-384. 


\section{$\underline{\text { Appendicies }}$}

\section{Appendix 1}

\section{Example of Data Analysis and Formation of Emergent Themes Interview Transcript (Rachel)}

Key:

Italic text refers to conceptual comments.

Underlined text refers to descriptive comments.

\begin{tabular}{|c|c|c|}
\hline Meaning unit & Exploratory Comment & Emergent Themes \\
\hline $\begin{array}{l}\text { INT: Can you put into } \\
\text { words your experience of } \\
\text { providing pain education } \\
\text { with patients with non- } \\
\text { specific low back pain. } \\
\text { Just take your time. } \\
\text { Rachel: Ok. } \\
\text { INT: So just generally. } \\
\text { Rachel: Where do I start? } \\
\text { Give me some pointers } \\
\text { where to start like as in? } \\
\text { INT: So just talk through } \\
\text { your general experience } \\
\text { of um, }\end{array}$ & $\begin{array}{l}\text { Rachel is being asked to talk and go } \\
\text { through their general experience of } \\
\text { providing pain education in the } \\
\text { context of NSLBP. } \\
\text { Rachel is unaware of where to start } \\
\text { could this imply her potential lack of } \\
\text { use of the intervention? Or } \\
\text { confusion of what the interviewer } \\
\text { was referring to as pain education? }\end{array}$ & $\begin{array}{l}\text { Assumption of physiotherapist's } \\
\text { potential lack of understanding } \\
\text { of pain education }\end{array}$ \\
\hline $\begin{array}{l}\text { Ok, I would say um, so } \\
\text { having to explain to } \\
\text { people } \\
\text { INT: } \mathrm{mm} \\
\text { Rachel: That they have } \\
\text { got non-specific lower } \\
\text { back pain. And then } \\
\text { getting that across in an } \\
\text { understandable } \\
\text { terminology. Because } \\
\text { when you say it's non- } \\
\text { specific they want a } \\
\text { structure. } \\
\text { INT: mm }\end{array}$ & $\begin{array}{l}\text { For Rachel pain education (begins } \\
\text { with?) providing an explanation for } \\
\text { the patient of their (diagnosis or the } \\
\text { cause) of NSLBP and what it means } \\
\text { in (layman) terms, that they can } \\
\text { understand. } \\
\text { Making an assumption of all people } \\
\text { with similar condition (NSLBP) } \\
\text { wanting a structure (of their } \\
\text { diagnosis or cause). Is she } \\
\text { stereotyping all people with this } \\
\text { condition behaving in a similar way } \\
\text { (Using the term "they"). According } \\
\text { to Rachel her responsibility is to } \\
\text { give a structure to the patient. By } \\
\text { saying "so having to explain" } \\
\text { reflects almost having an } \\
\text { obligation, chore or responsibility. } \\
\text { Is Rachel reluctant to provide pain } \\
\text { education? }\end{array}$ & $\begin{array}{l}\text { Physiotherapist's responsibility } \\
\text { or chore to provide pain } \\
\text { education? } \\
\text { Pain education as providing } \\
\text { explanation [in understandable } \\
\text { terminology] of their condition } \\
\text { Pain education as providing } \\
\text { structure of their condition }\end{array}$ \\
\hline $\begin{array}{l}\text { Rachel: And then you say } \\
\text { 'well there might not be a } \\
\text { structure.' And they're } \\
\text { like 'aw, ok.' }\end{array}$ & $\begin{array}{l}\text { Rachel is addressing that she may } \\
\text { not be able to highlight the } \\
\text { structure which she thinks the } \\
\text { patient thinks is causing NSLBP? }\end{array}$ & $\begin{array}{l}\text { Pain education as improving } \\
\text { patient understanding of the } \\
\text { diagnosis of NSLBP }\end{array}$ \\
\hline
\end{tabular}




\begin{tabular}{|c|c|c|}
\hline & $\begin{array}{l}\text { Rachel alludes that the patient may } \\
\text { not be satisfied or surprised that it } \\
\text { may not be a structure? What is this } \\
\text { structure she is referring to? What } \\
\text { is this structure meaning to her? } \\
\text { Does the participant have a lack of } \\
\text { understanding of NSLBP? }\end{array}$ & \\
\hline $\begin{array}{l}\text { And if they're not familiar } \\
\text { with the back also, so } \\
\text { then you have to go } \\
\text { through the anatomy, } \\
\text { possible sources of pain, } \\
\text { um and then kind of you } \\
\text { know possibly where } \\
\text { their pain could be } \\
\text { coming from, maybe } \\
\text { multiple areas and they } \\
\text { find that quite hard. }\end{array}$ & $\begin{array}{l}\text { Rachel talks through how she may } \\
\text { explain what is causing NSLBP. } \\
\text { Rachel infers that patients (if not } \\
\text { being familiar with the anatomy of } \\
\text { the back, or the possible sources of } \\
\text { pain) may find the explanation of } \\
\text { NSLBP (as suggested by Rachel } \\
\text { 'potentially coming from multiple } \\
\text { areas') difficult. } \\
\text { Rachel refers to the patients as } \\
\text { 'they' again. So, (is Rachel } \\
\text { suggesting that) if they were } \\
\text { familiar with the back you wouldn't } \\
\text { go through anatomy? } \\
\text { Rachel states that "you have to go } \\
\text { through the anatomy" again } \\
\text { reflects that this could be perceived } \\
\text { as an obligation? Is Rachel perhaps } \\
\text { reluctant or willing to provide } \\
\text { education? } \text { che participant } \\
\text { continues to describe that she may } \\
\text { explain the pain could be coming } \\
\text { from multiple areas inferring that } \\
\text { this could be purely a structural } \\
\text { problem? }\end{array}$ & $\begin{array}{l}\text { Pain education as providing } \\
\text { explanation of the possible } \\
\text { cause/s of pain } \\
\text { Pain education consisting of back } \\
\text { anatomy } \\
\text { Patients having difficulty } \\
\text { understanding condition [and } \\
\text { pain education] } \\
\text { Assumption of physiotherapist } \\
\text { focusing on mechanical } \\
\text { problem? [which may reflect } \\
\text { physiotherapist's mechanical } \\
\text { beliefs of NSLBP] }\end{array}$ \\
\hline $\begin{array}{l}\text { I think cus a lot of people, } \\
\text { you know they want a } \\
\text { diagnosis, they want a } \\
\text { structure. }\end{array}$ & $\begin{array}{l}\text { Rachel states that patients desire a } \\
\text { diagnosis and infers that } \\
\text { participants desire a structural } \\
\text { explanation to their NSLBP. (How } \\
\text { does she know this? Is this being } \\
\text { assumed?) Is referring to 'a lot of } \\
\text { people' stereotyping patients living } \\
\text { with NSLBP? Is Rachel inferring that } \\
\text { NSLBP is not a diagnosis? }\end{array}$ & $\begin{array}{l}\text { Pain education as providing a } \\
\text { diagnosis } \\
\text { Pain education as providing a } \\
\text { 'structure' } \\
\text { Assumption of patients require } \\
\text { structural explanation for } \\
\text { diagnosis }\end{array}$ \\
\hline $\begin{array}{l}\text { And then they go away, } \\
\text { and they google it, and if } \\
\text { they don't get that } \\
\text { information, they feel } \\
\text { like mm, don't really } \\
\text { know what I'm talking } \\
\text { about you know, they } \\
\text { don't think you know }\end{array}$ & $\begin{array}{l}\text { Rachel assumes/suggests that } \\
\text { (after being seen by a } \\
\text { physiotherapist) patients may be } \\
\text { lacking information they wanted } \\
\text { from the therapist and therefore } \\
\text { seek further information and still } \\
\text { may not understand what has been } \\
\text { said. }\end{array}$ & $\begin{array}{l}\text { Assumption that patients may } \\
\text { seek further/additional } \\
\text { information regarding NSLBP } \\
\text { Assumption of patients possibly } \\
\text { lacking understanding following } \\
\text { explanation of diagnosis }\end{array}$ \\
\hline
\end{tabular}




\begin{tabular}{|c|c|c|}
\hline $\begin{array}{l}\text { what you're talking } \\
\text { about. }\end{array}$ & $\begin{array}{l}\text { Rachel assumes/suggests that this } \\
\text { lack of information from the } \\
\text { physiotherapist can lead to the } \\
\text { patient thinking the physiotherapist } \\
\text { did not really know what she was } \\
\text { talking about. Participants use of } \\
\text { google may indicate that no advice } \\
\text { was provided where to look for } \\
\text { further information? Participant } \\
\text { repeats that patients may not know } \\
\text { what she is talking about. Is this } \\
\text { because this is something that } \\
\text { concerns/worries/frustrates her? }\end{array}$ & $\begin{array}{l}\text { Assumption of lack of } \\
\text { information leading to patients } \\
\text { having doubts } \\
\text { Assumption that physiotherapist } \\
\text { feels obligated to explain to } \\
\text { patient about their structural } \\
\text { cause of pain }\end{array}$ \\
\hline $\begin{array}{l}\text { Um, so yeah, so a lot of } \\
\text { that kind of getting that } \\
\text { diagnosis across and then } \\
\text { educating the patient on } \\
\text { the back and why it's } \\
\text { non-specific and why an } \\
\text { x-ray or an MRI might not } \\
\text { give them an indication } \\
\text { of what structure is } \\
\text { wrong with their back or } \\
\text { as it's nothing it may be } \\
\text { the way they move, um } \\
\text { their lifestyle issues, } \\
\text { muscle tightness, muscle } \\
\text { weakness and is an } \\
\text { accumulation of things } \\
\text { that's just loading the } \\
\text { back. That's generally } \\
\text { how I would put it across. }\end{array}$ & $\begin{array}{l}\text { Participant describes that she } \\
\text { provides an explanation of the } \\
\text { diagnosis prior to educating the } \\
\text { patient further regarding the back } \\
\text { and why it may be non-specific. She } \\
\text { highlights that the way a patient } \\
\text { moves, their lifestyle or mechanical } \\
\text { issues (tightness/weakness) may be } \\
\text { causing their NSLBP. She infers that } \\
\text { such issues may be "loading the } \\
\text { back" which may contribute to pain. } \\
\text { This appears to represent } \\
\text { mechanical contributing factors to } \\
\text { pain. Does Rachel have potential } \\
\text { mechanical beliefs about NSLBP } \\
\text { which may influence mechanical } \\
\text { based pain education regarding the } \\
\text { patients diagnosis? She uses the } \\
\text { language "it's nothing" what does } \\
\text { she mean by this? She states how } \\
\text { she "generally" conveys this } \\
\text { information. Is this lack of } \\
\text { individualisation? The participant } \\
\text { refers to this as 'putting it across'. Is } \\
\text { this implying that it isn't much of a } \\
\text { conversation, more of a didactic } \\
\text { approach? }\end{array}$ & $\begin{array}{l}\text { Pain education as an explanation } \\
\text { of NSLBP. } \\
\text { Assumption of Rachel possessing } \\
\text { mechanical beliefs causing } \\
\text { NSLBP [which may influence } \\
\text { subsequent pain education] } \\
\text { Pain education as explaining the } \\
\text { mechanical factors which may be } \\
\text { causing the patient's pain } \\
\text { Is pain education didactic? } \\
\text { Pain education not } \\
\text { individualised }\end{array}$ \\
\hline $\begin{array}{l}\text { So I would just go } \\
\text { through anatomy, um } \\
\text { what I found in the } \\
\text { objective, so weather } \\
\text { there is a um you know } \\
\text { they've got a stiff back, if } \\
\text { they've got muscle } \\
\text { weakness, } \\
\text { tightness. And then I'll } \\
\text { say all of those things can } \\
\text { be a possible source of }\end{array}$ & $\begin{array}{l}\text { Participant summarises that she } \\
\text { initiates the conversation with } \\
\text { "going through" anatomy and } \\
\text { describing the objective findings } \\
\text { (potential weakness/ tightness). } \\
\text { The objective assessment seems } \\
\text { important for Rachel to inform her } \\
\text { of the patients diagnosis so she can } \\
\text { inform the patients of this. She then } \\
\text { states that all of this may be a } \\
\text { potential source of pain. Repeated }\end{array}$ & $\begin{array}{l}\text { Pain education as 'going } \\
\text { through' (back?) anatomy } \\
\text { Pain education as explaining the } \\
\text { relationship between objective } \\
\text { assessment and NSLBP } \\
\text { Pain education as explaining the } \\
\text { [mechanical factors as a } \\
\text { potential] source of pain }\end{array}$ \\
\hline
\end{tabular}




\begin{tabular}{|c|c|c|}
\hline $\begin{array}{l}\text { pain and then effects } \\
\text { how you move. }\end{array}$ & $\begin{array}{l}\text { reference to patient as 'they' } \\
\text { stereotypical? Participant outlines } \\
\text { that mechanical issues may affect } \\
\text { the way a patient moves but does } \\
\text { not elaborate how reduced moving } \\
\text { may impact patient. }\end{array}$ & \\
\hline $\begin{array}{l}\text { Then you then stretching } \\
\text { structures that haven't } \\
\text { been stretched um, that } \\
\text { can cause you pain. It can } \\
\text { be the way that you're } \\
\text { sitting, your lifestyle } \\
\text { issues, it's just all loading } \\
\text { those structures and it's } \\
\text { not conducive to you } \\
\text { know good biomechanics } \\
\text { and getting rid of back } \\
\text { pain basically. }\end{array}$ & 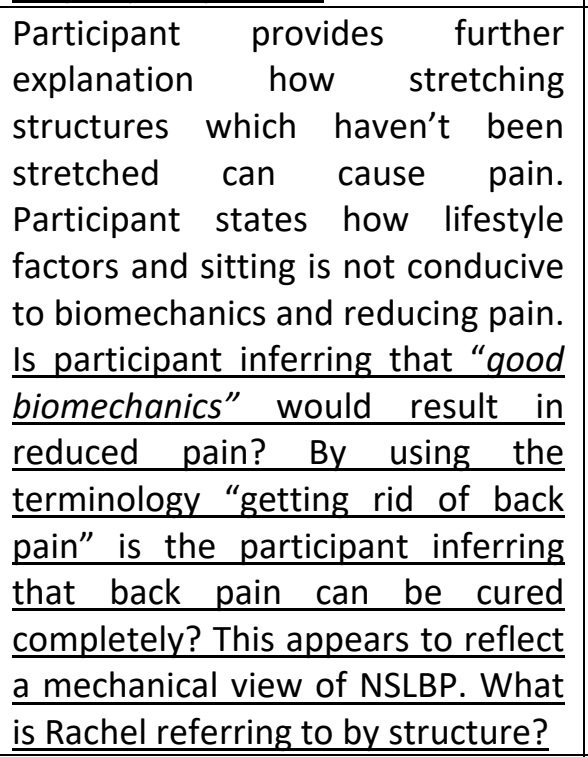 & $\begin{array}{l}\text { Pain education as explaining the } \\
\text { relationship between } \\
\text { biomechanics and pain } \\
\text { Pain education as highlighting } \\
\text { the structures causing pain } \\
\text { Assumption of physiotherapists } \\
\text { mechanical beliefs regarding } \\
\text { NSLBP influencing pain } \\
\text { education }\end{array}$ \\
\hline $\begin{array}{l}\text { So yeah for me it's all } \\
\text { about education I would } \\
\text { say. And hopefully that } \\
\text { they, you know by } \\
\text { explaining that hopefully } \\
\text { in the right terms, in } \\
\text { layman's terms that they } \\
\text { get you what you're } \\
\text { talking about. They don't } \\
\text { go away and go 'I don't } \\
\text { know what she's talking } \\
\text { about.' }\end{array}$ & $\begin{array}{l}\text { Participant highlights that } \\
\text { education is important to her and } \\
\text { that she hopes patients understand } \\
\text { what she is talking about. } \\
\text { Participant says "hopefully in the } \\
\text { right terms" which suggests that } \\
\text { occasionally this may not occur and } \\
\text { there are possible consequences for } \\
\text { not using the 'right' terms. She } \\
\text { repeats "They don't go away and go } \\
\text { 'I don't know what she's talking } \\
\text { about". Is this a concern for her? } \\
\text { Does she use "Layman's" terms to } \\
\text { improve their understanding? }\end{array}$ & $\begin{array}{l}\text { (pain?) Education is important } \\
\text { (pain) Education as explanation } \\
\text { Pain education as Improving } \\
\text { patient understanding of their } \\
\text { condition. } \\
\text { Using layman's terms during } \\
\text { (pain?) education. }\end{array}$ \\
\hline $\begin{array}{l}\text { INT: Yeah definitely. And } \\
\text { what did you mean by } \\
\text { Layman's terms? } \\
\text { Rachel: So Layman's } \\
\text { terms that they don't } \\
\text { understand, they } \\
\text { understand the } \\
\text { terminology that I might } \\
\text { use like a disc or facet } \\
\text { joint. So I'll just say the } \\
\text { joints in your back. So } \\
\text { something that's easy for } \\
\text { them to understand }\end{array}$ & $\begin{array}{l}\text { The participant elaborates what she } \\
\text { meant by Layman's terms. The } \\
\text { participant explains that Layman's } \\
\text { terms are utilised as they're easy for } \\
\text { patients to understand. "Disc, facet, } \\
\text { joints" are all structural, participant } \\
\text { appears to refer to structures } \\
\text { repetitively. }\end{array}$ & $\begin{array}{l}\text { Use of Layman's terms [during } \\
\text { pain education] are easier to } \\
\text { understand. }\end{array}$ \\
\hline
\end{tabular}




\begin{tabular}{|c|c|c|}
\hline $\begin{array}{l}\text { And then I may use, um I } \\
\text { know, I might sort of take } \\
\text { a scenario of everyday } \\
\text { life. So like um, I don't } \\
\text { know, your car, you know } \\
\text { you need to oil a few } \\
\text { little parts of your car } \\
\text { when they get a bit rusty, } \\
\text { just like that with your } \\
\text { back when your joints get } \\
\text { a little bit like that. So l'Il } \\
\text { just kinda relate it to an } \\
\text { everyday activity. } \\
\text { INT: mm. } \\
\text { Rachel: } \\
\text { they're interested in. So } \\
\text { if they're interested in } \\
\text { cars, and they know that } \\
\text { they're tinkering around } \\
\text { with the cars and things } \\
\text { are getting a bit rusty, l'Il } \\
\text { just say that's like your } \\
\text { back basically. } \\
\text { INT: Yeah. }\end{array}$ & $\begin{array}{l}\text { Participant provides example of } \\
\text { analogy which relates to everyday } \\
\text { life. Participant attempts to make } \\
\text { analogy person centred and } \\
\text { compare something which interests } \\
\text { the patient. Participant uses } \\
\text { metaphor and compares joints of } \\
\text { back to rusty car parts. } \\
\text { This metaphor refers to structural } \\
\text { problem again ('rusty'). This } \\
\text { analogy reflects a simplistic } \\
\text { approach to NSLBP. IS Rachel using } \\
\text { this analogy to describe how } \\
\text { interventions may help with NSLBP? } \\
\text { l.e if the car is rusty is she using this } \\
\text { to inform the patient that they } \\
\text { would remove the rust from their } \\
\text { car? }\end{array}$ & $\begin{array}{l}\text { Pain education as using } \\
\text { analogies to explain } \\
\text { symptoms/condition/issue? } \\
\text { Individualised analogy } \\
\text { Assumption of physiotherapist's } \\
\text { mechanical beliefs regarding } \\
\text { NSLBP } \\
\text { Assumption of physiotherapist's } \\
\text { simplistic approach to NSLBP }\end{array}$ \\
\hline $\begin{array}{l}\text { Rachel: Um, so yeah just } \\
\text { kind of relate it to } \\
\text { something that they may } \\
\text { understand. Weather } \\
\text { that's their hobby or } \\
\text { their job or something } \\
\text { like that. And they tend, } \\
\text { tend to get it. Generally, } \\
\text { the car is a good one. Like } \\
\text { the servicing of a car you } \\
\text { know. } \\
\text { INT: mm. }\end{array}$ & $\begin{array}{l}\text { Participant reiterates that she } \\
\text { relates explanation to something a } \\
\text { patient would understand. She } \\
\text { states that participants 'tend' to get } \\
\text { it. This may imply that not all } \\
\text { patients understand. }\end{array}$ & $\begin{array}{l}\text { Relating (pain?) education to } \\
\text { everyday life to enhance } \\
\text { understanding. } \\
\text { Not all patients understand pain } \\
\text { education? }\end{array}$ \\
\hline $\begin{array}{l}\text { Rachel: I'll just say you } \\
\text { know, there are all of } \\
\text { these things that you } \\
\text { haven't been looking } \\
\text { after, um and you would } \\
\text { do that for your car } \\
\text { wouldn't you? You know } \\
\text { change the oil, and } \\
\text { change the breakpads. }\end{array}$ & $\begin{array}{l}\text { Participant continues to compare } \\
\text { looking after the car and not looking } \\
\text { after themselves. It seems as } \\
\text { though an element of blame is } \\
\text { placed on participant ("you haven't } \\
\text { been looking after). She almost } \\
\text { belittles patient by saying "you } \\
\text { would do that for your car". } \\
\text { Suggests its simple. As Rachel is } \\
\text { implying that the patient has not } \\
\text { been looking after these 'things' } \\
\text { does this reflect the mechanical } \\
\text { focus of NSLBP? Is Rachel } \\
\text { comparing change the oil and break }\end{array}$ & $\begin{array}{l}\text { Pain education as using } \\
\text { analogies to explain } \\
\text { symptoms/condition/issue? }\end{array}$ \\
\hline
\end{tabular}




\begin{tabular}{|c|c|c|}
\hline & $\begin{array}{l}\text { help with NSLBP? Is Rachel using } \\
\text { education to explain how } \\
\text { interventions can help with NSLBP? }\end{array}$ & \\
\hline $\begin{array}{l}\text { And you're doing } \\
\text { nothing, you're not } \\
\text { stretching you're not } \\
\text { strengthening, you're } \\
\text { not moving, you're not } \\
\text { servicing your body. And } \\
\text { that all adds up to kind of } \\
\text { pain and you know } \\
\text { whatever structure I } \\
\text { think potentially is at } \\
\text { fault. }\end{array}$ & $\begin{array}{l}\text { Participant infers that pain is } \\
\text { contributed by doing nothing, not } \\
\text { stretching, moving. Repeats } \\
\text { metaphoric language by comparing } \\
\text { car to body ("servicing your body"). } \\
\text { She then states that structure may } \\
\text { be at "fault". This implies that } \\
\text { structure can contribute to pain. } \\
\text { The analogy does not particularly } \\
\text { reflect a biopsychosocial } \\
\text { explanation to pain, it focuses on } \\
\text { structural issues. Enforcing patient } \\
\text { to blame and their actions of not } \\
\text { stretching, strengthening or moving } \\
\text { may have contributed to pain. Does } \\
\text { Rachel have biomedical and/or } \\
\text { strict mechanical views for NSLBP? } \\
\text { Emphasis appears to be on } \\
\text { structures. }\end{array}$ & $\begin{array}{l}\text { Assumption that pain education } \\
\text { highlights patient is to blame for } \\
\text { pain } \\
\text { Pain education as highlighting } \\
\text { the structural/mechanical } \\
\text { factors contributing to pain }\end{array}$ \\
\hline $\begin{array}{l}\text { INT: Definitely. Yeah, } \\
\text { thank you very much. } \\
\text { Now can you go through } \\
\text { a concrete situation } \\
\text { where you have provided } \\
\text { pain education, with one } \\
\text { patient with non-specific } \\
\text { low back pain. } \\
\text { Rachel: A particular } \\
\text { patient yeah? } \\
\text { INT: Yeah, try to talk } \\
\text { through your own } \\
\text { actions in that situation } \\
\text { as concretely and in as } \\
\text { much detail as possible. } \\
\text { Just take your time there } \\
\text { is no rush. } \\
\text { Rachel: Um, let me think } \\
\text { about a patient. Um, aw } \\
\text { ok, I've got a guy I had in } \\
\text { today. } \\
\text { INT: Ok. }\end{array}$ & $\begin{array}{l}\text { Interviewer asking patient to talk } \\
\text { through a concrete situation of } \\
\text { providing pain education in context } \\
\text { of managing NSLBP. Participant } \\
\text { highlights she will talk about a } \\
\text { patient she had seen that day. }\end{array}$ & \\
\hline $\begin{array}{l}\text { Rachel: Um, he is, it's } \\
\text { non-specific in the sense } \\
\text { he is just kind of getting } \\
\text { achy in his muscles so } \\
\text { and achy in his joints. It's } \\
\text { not like you know he's } \\
\text { got wear and tear, he's }\end{array}$ & $\begin{array}{l}\text { Patient explains why the patient has } \\
\text { non-specific pain by excluding other } \\
\text { issues. Does not elaborate why } \\
\text { patients pain is NSLBP. "Wear and } \\
\text { tear"and "Disc" is structural } \\
\text { language which conveys the } \\
\text { structural emphasis this participant }\end{array}$ & $\begin{array}{l}\text { Assumption of physiotherapist's } \\
\text { lack of understanding of NSLBP }\end{array}$ \\
\hline
\end{tabular}




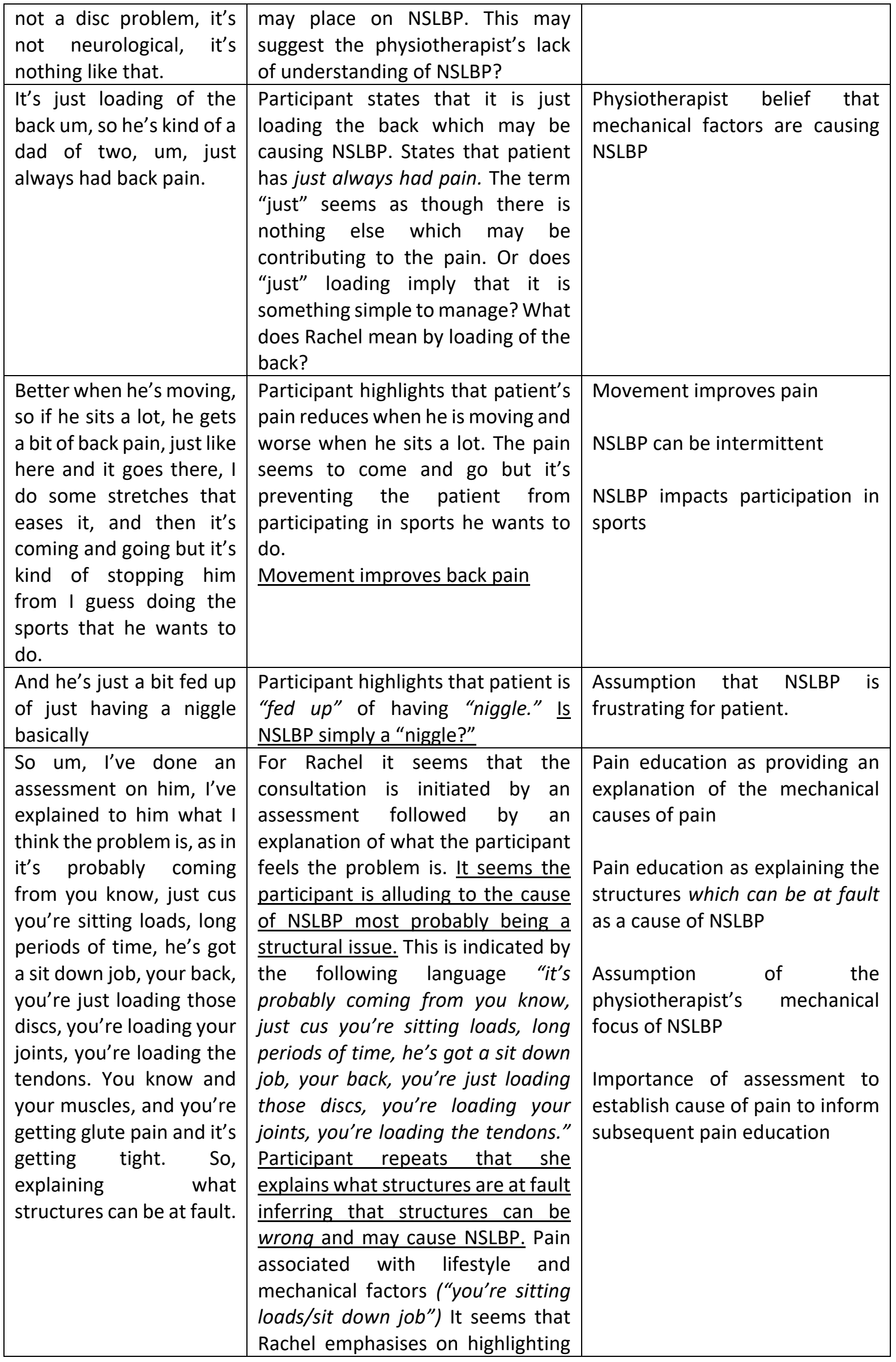




\begin{tabular}{|c|c|c|}
\hline & $\begin{array}{l}\text { that mechanical factors may be a } \\
\text { cause of NSLBP }\end{array}$ & \\
\hline $\begin{array}{l}\text { And then we looked at } \\
\text { um, you know as there } \\
\text { wasn't any particular } \\
\text { structure, we looked at } \\
\text { how he moved. Um, cus } \\
\text { he was finding that } \\
\text { certain things he couldn't } \\
\text { do. Like squats would } \\
\text { load his back a little bit } \\
\text { too much and he didn't } \\
\text { really understand why. } \\
\text { INT: mm. }\end{array}$ & $\begin{array}{l}\text { Participant was unable to identify } \\
\text { structure problem so looked at how } \\
\text { patient moved. (As this may have } \\
\text { contributed to NSLBP?) Further } \\
\text { emphasis on mechanical faults } \\
\text { contributing to NSLBP. Is this the } \\
\text { participants or patients beliefs 'that } \\
\text { squats would load the back too } \\
\text { much? Rachel describes that } \\
\text { patient did not understand why his } \\
\text { back was being loaded too much } \\
\text { which infers that the patient's } \\
\text { knowledge is lacking regarding this } \\
\text { issue. Seems that again there is } \\
\text { opportunity for participant to } \\
\text { educate. }\end{array}$ & $\begin{array}{l}\text { Importance of assessment to } \\
\text { inform cause of pain to educate } \\
\text { patient about NSLBP cause } \\
\text { Mechanical factors contributing } \\
\text { to NSLBP } \\
\text { Assumption that patients lack } \\
\text { understanding of why pain is } \\
\text { occurring, highlighting } \\
\text { opportunity for education }\end{array}$ \\
\hline $\begin{array}{l}\text { So, um we did some } \\
\text { movement control test, } \\
\text { um looking at the lumbar } \\
\text { spine, and how it moved. } \\
\text { INT: mm. } \\
\text { Rachel: Um, and he was } \\
\text { like more of an anterior } \\
\text { tilt, so he was just kind of } \\
\text { arching his back quite a } \\
\text { lot which is loading his } \\
\text { lower back. } \\
\text { INT: mm }\end{array}$ & 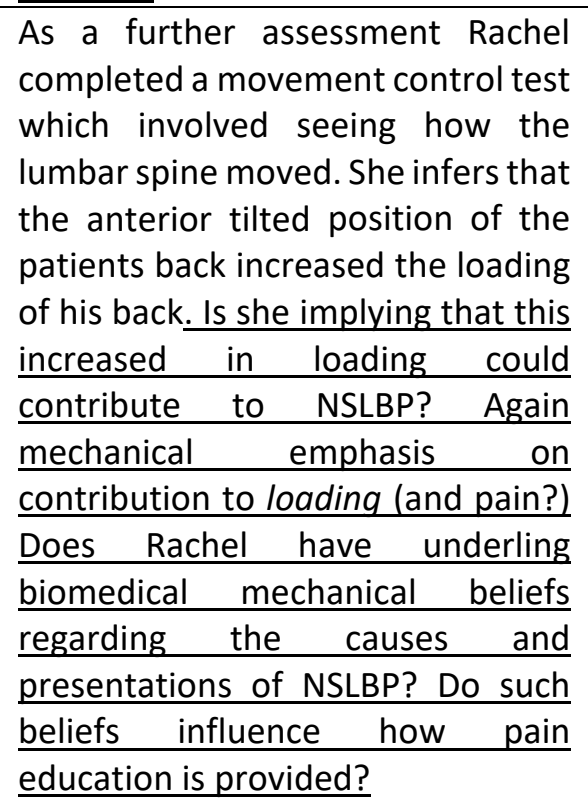 & $\begin{array}{l}\text { Movement assessment for } \\
\text { NSLBP to inform pain } \\
\text { contributing factors } \\
\text { Pelvic position (posture) relating } \\
\text { to increased 'load' (pain?) } \\
\begin{array}{l}\text { Physiotherapists mechanical } \\
\text { beliefs regarding NSLBP }\end{array}\end{array}$ \\
\hline $\begin{array}{l}\text { Umm, and then so from } \\
\text { there kinda taught him } \\
\text { neutral spine, um what } \\
\text { muscles potentially } \\
\text { control that pelvis, back } \\
\text { into that posterior tilt. }\end{array}$ & $\begin{array}{l}\text { Rachel explains that she taught the } \\
\text { patient 'neutral spine' and went } \\
\text { through which muscles control can } \\
\text { help return to posterior tilt. More } \\
\text { anatomical based education. Is } \\
\text { Rachel inferring that mechanical } \\
\text { changes (posterior tilting) can help } \\
\text { NSLBP? Rachel uses language such } \\
\text { as 'kinda' does this suggest that } \\
\text { there wasn't much } \\
\text { focus/emphasis/efforts placed on } \\
\text { this section? }\end{array}$ & $\begin{array}{l}\text { Pain education as explaining } \\
\text { lower back muscular anatomy } \\
\text { (to improve posture). }\end{array}$ \\
\hline $\begin{array}{l}\text { Um, and then we looked } \\
\text { at gym exercises, } \\
\text { because he wants to get } \\
\text { back to the gym. So we }\end{array}$ & $\begin{array}{l}\text { Rachel explains that the used gym } \\
\text { exercises as an assessment as the } \\
\text { patient wanted to get back to the } \\
\text { gym. Rachel states that they did }\end{array}$ & $\begin{array}{l}\text { Significance of movement } \\
\text { assessment for NSLBP to inform } \\
\text { pain contributing factors [to } \\
\text { inform pain education?] }\end{array}$ \\
\hline
\end{tabular}




\begin{tabular}{|c|c|c|}
\hline $\begin{array}{l}\text { looked at squatting } \\
\text { umm, deadlifts and } \\
\text { lunges. With all that kind } \\
\text { of glute activation and } \\
\text { neutral spine. }\end{array}$ & $\begin{array}{l}\text { exercises such as squatting deadlifts } \\
\text { and lunges with "all that kind of } \\
\text { glute activation and neutral spine." } \\
\text { Patient wanted to get back to gym } \\
\text { so utilising assessment based on } \\
\text { patients desires (Not sure this is } \\
\text { reflected in whole text). The use of } \\
\text { 'kind of glute activation and neutral } \\
\text { spine' may imply a lack of } \\
\text { understanding and categorising } \\
\text { many potential exercises under one } \\
\text { name. Rachel does not specify her } \\
\text { actions which may indicate her lack } \\
\text { of interest in the topic. }\end{array}$ & $\begin{array}{l}\text { Emphasis on neutral spine and } \\
\text { posture to help with NSLBP }\end{array}$ \\
\hline $\begin{array}{l}\text { Um, and then so we did a } \\
\text { gym session today with } \\
\text { squatting cus he thought } \\
\text { 'aw I won't be able, I } \\
\text { can't do squats because } \\
\text { it hurts my back.' } \\
\text { INT: mm.. }\end{array}$ & $\begin{array}{l}\text { Rachel highlights that they did gym } \\
\text { session which included squatting as } \\
\text { the patient presented with negative } \\
\text { beliefs regarding squatting that it } \\
\text { may hurt his back. Rachel } \\
\text { challenging patient beliefs. Rachel } \\
\text { seems to be encouraging exercise } \\
\text { with patients with NSLBP. Was this } \\
\text { 'treatment' utilised because Rachel } \\
\text { thought is was best for patient? No } \\
\text { reference to shared decision } \\
\text { making here. }\end{array}$ & $\begin{array}{l}\text { Exercise for NSLBP } \\
\text { Assumption that physiotherapist } \\
\text { assist to overcome pain related } \\
\text { fear } \\
\text { Physiotherapist deciding rehab } \\
\text { independently }\end{array}$ \\
\hline $\begin{array}{l}\text { Rachel: Then I videoed } \\
\text { him as well, looked um, } \\
\text { showed him how he was } \\
\text { moving and he could see } \\
\text { that his back wasn't in a } \\
\text { good position when he } \\
\text { was squatting. And that } \\
\text { gave him that kind of } \\
\text { feedback, he could see it, } \\
\text { so when he could see it } \\
\text { he was like 'aw ok, I can } \\
\text { see what's happening } \\
\text { now.' } \\
\text { INT: mm }\end{array}$ & $\begin{array}{l}\text { Rachel states that she used video } \\
\text { recorded the patient when he was } \\
\text { squatting to provide the patient } \\
\text { with feedback of his position. She } \\
\text { indicates that the participant could } \\
\text { understand what was happening to } \\
\text { his back after seeing the video. } \\
\text { Rachel continues to emphasise } \\
\text { movement and mechanics during } \\
\text { an assessment. }\end{array}$ & $\begin{array}{l}\text { Pain education as highlighting } \\
\text { poor movement which may be } \\
\text { causing pain } \\
\text { Movement assessment for } \\
\text { NSLBP } \\
\text { Video assessment to highlight } \\
\text { movements which may be } \\
\text { contributing to pain [to inform } \\
\text { patient of pain contributing } \\
\text { factors?] }\end{array}$ \\
\hline $\begin{array}{l}\text { Rachel: That helped then } \\
\text { with the exercises } \\
\text { because I would give him } \\
\text { certain exercises that } \\
\text { would control his lumbar } \\
\text { spine so he wouldn't arch } \\
\text { his back. And that, }\end{array}$ & $\begin{array}{l}\text { Rachel provides patient with } \\
\text { exercise to help control lumbar } \\
\text { spine. (This is not advocated in } \\
\text { literature when provided in } \\
\text { isolation). Why would providing } \\
\text { feedback 'help with the exercises?' } \\
\text { (?'Buy in') It seems Rachel is } \\
\text { providing patient exercise to help }\end{array}$ & $\begin{array}{l}\text { Providing [lumbar spine } \\
\text { stability/[postural] exercise for } \\
\text { patient with NSLBP }\end{array}$ \\
\hline
\end{tabular}




\begin{tabular}{|c|c|c|}
\hline $\begin{array}{l}\text { because he could see it, } \\
\text { that helped him. }\end{array}$ & $\begin{array}{l}\text { with arching of back, is this to help } \\
\text { with NSLBP? }\end{array}$ & $\begin{array}{l}\text { potential contributing factors to } \\
\text { NSLBP }\end{array}$ \\
\hline $\begin{array}{l}\text { And then, he's gone away } \\
\text { and done his exercises } \\
\text { and actually he's a lot } \\
\text { better this week, he still } \\
\text { gets a bit of an achy back } \\
\text { but he knows what it is, } \\
\text { he knows what brings it } \\
\text { on, how to change it, } \\
\text { how to manage it and } \\
\text { he's starting to go back to } \\
\text { the gym. }\end{array}$ & $\begin{array}{l}\text { The patient seems to have } \\
\text { responded well and is getting 'a lot } \\
\text { better'. The patient still gets an } \\
\text { achy back but knows how to } \\
\text { manage it and is starting to go back } \\
\text { to the gym. For Rachel it seems that } \\
\text { if the patient still has a slightly achy } \\
\text { back, its okay because the patient } \\
\text { knows how to manage it. Is Rachel } \\
\text { recognising that its important for } \\
\text { patient to be able to manage pain } \\
\text { independently? Although the } \\
\text { literature highlights that emphasis } \\
\text { on mechanical factors is not helpful } \\
\text { for patients with NSLBP, can it be } \\
\text { helpful for some people? Rachel } \\
\text { describes how the patient knows } \\
\text { what his pain is and how to change } \\
\text { it and how to manage it. But it } \\
\text { seems he hasn't been informed of } \\
\text { the complexities and details of } \\
\text { NSLBP? Could this help with being } \\
\text { able to manage it? }\end{array}$ & $\begin{array}{l}\text { Patient 'knows' how to change } \\
\text { and manage pain. } \\
\text { Pain education to inform patient } \\
\text { of diagnosis and how to manage } \\
\text { it }\end{array}$ \\
\hline $\begin{array}{l}\text { INT: Brilliant. Fantastic. } \\
\text { That sounds like quite a } \\
\text { good situation there. } \\
\text { Rachel: mm. Well a lot of } \\
\text { them I would say is it's } \\
\text { like that because when } \\
\text { it's non-specific you're } \\
\text { thinking, ok what, in this } \\
\text { clinic specifically, we look } \\
\text { at why they're getting it. } \\
\text { INT: mm.. }\end{array}$ & $\begin{array}{l}\text { Interviewer rounding off question } \\
\text { to prepare for next question. Rachel } \\
\text { begins to summarise her answers } \\
\text { by saying that her and the staff in } \\
\text { the clinic seek the cause of NSLBP. } \\
\text { Is this to inform subsequent pain } \\
\text { education regarding the cause of } \\
\text { NSLBP? She refers to how her } \\
\text { previous conversations relate to "a } \\
\text { lot of them". Is she stereotyping } \\
\text { patients with NSLBP? }\end{array}$ & $\begin{array}{l}\text { Similar approach to a lot of } \\
\text { patients with NSLBP. } \\
\text { Physiotherapist seek cause for } \\
\text { NSLBP [to inform patient of this } \\
\text { as part of pain education?] }\end{array}$ \\
\hline $\begin{array}{l}\text { Rachel: Ok, so you kind of } \\
\text { just have to ask them } \\
\text { loads of questions about } \\
\text { their lifestyle. } \\
\text { INT: mm } \\
\text { Rachel: Umm, in most } \\
\text { people it's just cus } \\
\text { they're just sitting and } \\
\text { not moving a lot. } \\
\text { INT: mm. }\end{array}$ & $\begin{array}{l}\text { Rachel highlights the necessity to } \\
\text { ask lifestyle questions. She then } \\
\text { again infers that NSLPB is caused by } \\
\text { 'sitting and not moving a lot.' } \\
\text { "Kind of" may imply potential } \\
\text { doubt, is it not done whole } \\
\text { heartedly? The language 'just have } \\
\text { to' portrays something as being } \\
\text { easy and basic? Or is asking lifestyle } \\
\text { questions something Rachel feels } \\
\text { obligated to do? Does Rachel } \\
\text { explore a patient's beliefs which } \\
\text { may impact NSLBP? }\end{array}$ & $\begin{array}{l}\text { [Pain education] informed by } \\
\text { exploring lifestyle }\end{array}$ \\
\hline
\end{tabular}


Rachel: So then, you try and kind of get to specifics as to why their loading their back basically and why they're getting that pain. And for me and for this clinic, it all comes down to how someone moves basically. INT: $\mathrm{mm}$.

Rachel: And then what is preventing that person from moving properly. So weather that's a strength issue, or um a flexibility issue, um you know muscle, brain connection type issue. And then you know ruling whatever out or weakness and then finding a treatment plan for them.

INT: Can you tell me what you meant by a movement issue?

Rachel: So for example, you know I would say to someone umm, 'you can walk.' They're like yeah. Like, I'll say to them like, they're like, 'well I'm getting knee pain but l'm, say I'm running.' Ok, so someone running. And they're like 'well, I think I'm running ok, but I'm
Rachel tries to establish why a patient is loading their back and why they're getting pain. She admits that for her and the clinic it comes down to the way someone moves (basically). Is there not anything else that it could be? Speaking on behalf of the clinic.

It seems that why the patient is loading the back is more important to Rachel than the cause and contributing factors of NSLBP. Mechanical factors seems to be the most obvious and important reasons for causing pain according to Rachel. Why is Rachel so concerned about loading the back if it is a separate matter to why patients are getting their pain? Looking at the 'specifics' may imply that this is something which requires effort and attention to detail.

For Rachel it is important to highlight what is preventing the patient from moving properly examples are provided such as flexibility and muscle. Rachel states that she will provide a treatment plan based on these objective findings.

What is preventing the person from moving properly is then addressed after pain. Is this really important for Rachel and or the patient? Would 'moving properly' reduce pain?

The interviewer asks Rachel to elaborate on what she meant by a movement issue. Rachel explains that someone an do an activity such as running, but not do it 'well.'
Importance of assessment to establish why a patient is loading their back [to inform patient of potential cause of pain?]

Physiotherapist focusing on mechanical factors as a cause of NSLBP

Treatment related to objective findings

Mechanical 'issues' preventing person from moving properly

Poor movement $=$ pain?

Pain education as highlighting 'poor movement' [as a contributing factor to NSLBP] 


\begin{tabular}{|c|c|c|}
\hline $\begin{array}{l}\text { getting knee pain.' l'm } \\
\text { like yeah but you're } \\
\text { running, but you're not } \\
\text { running well. } \\
\text { INT: } m \text { m. }\end{array}$ & & \\
\hline $\begin{array}{l}\text { Rachel: Ok. And they're } \\
\text { like 'well what do you } \\
\text { mean by that?' And I'll } \\
\text { say well, you could have } \\
\text { someone with say like a } \\
\text { stroke. But one side of } \\
\text { their body isn't working, } \\
\text { but they're still walking. } \\
\text { They're still moving but } \\
\text { they're not moving well. } \\
\text { They're having to } \\
\text { compensate. And they're } \\
\text { like ok. So I said like ok } \\
\text { 'you're moving, your } \\
\text { muscles are working, but } \\
\text { they're not maybe } \\
\text { working in the right way.' } \\
\text { INT: mm. }\end{array}$ & $\begin{array}{l}\text { Rachel implies that patients often } \\
\text { are still confused following } \\
\text { explanation of 'movement issue.' } \\
\text { She uses a metaphor of patient with } \\
\text { a stroke and poor movement to } \\
\text { compare and inform the patient } \\
\text { how they may be moving but not } \\
\text { moving in the right way. Is there a } \\
\text { right way to move? }\end{array}$ & $\begin{array}{l}\text { Using patient with stroke to } \\
\text { educate poor movement } \\
\text { Pain education as explaining the } \\
\text { mechanical factors potentially } \\
\text { contributing to NSLBP } \\
\text { Pain education as highlighting } \\
\text { poor movement [as a } \\
\text { contributing factor to NSLBP] }\end{array}$ \\
\hline $\begin{array}{l}\text { Rachel: So you might sort } \\
\text { of I don't know maybe if } \\
\text { you've got weakness } \\
\text { somewhere, your body is } \\
\text { having to then } \\
\text { compensate for that } \\
\text { weakness. You're still } \\
\text { allowed, you're still } \\
\text { moving but it's not } \\
\text { efficient. Then that's } \\
\text { then what's loading that } \\
\text { knee or that hip. } \\
\text { INT: mm.. }\end{array}$ & $\begin{array}{l}\text { Rachel believes that if there is a } \\
\text { weakness within the body, the body } \\
\text { will compensate which may } \\
\text { contribute to inefficient movement. } \\
\text { For Rachel, it is this compensation } \\
\text { which is contributing to the } \\
\text { increased loading of structures. } \\
\text { Why is loading' structures such a } \\
\text { problem for Rachel? }\end{array}$ & $\begin{array}{l}\text { Pain education as explaining the } \\
\text { relationship between } \\
\text { mechanical factors contributing } \\
\text { to increased loading and pain }\end{array}$ \\
\hline $\begin{array}{l}\text { Rachel: That's what, so } \\
\text { we are looking, we'll do } \\
\text { that specific test, to look } \\
\text { at how someone moves. }\end{array}$ & $\begin{array}{l}\text { Rachel implies that her and (staff at } \\
\text { the clinic?) will do a specific test to } \\
\text { see how someone moves. }\end{array}$ & $\begin{array}{l}\text { Importance of a movement } \\
\text { assessment for NSLBP [to inform } \\
\text { pain contributing factors to } \\
\text { NSLBP?] }\end{array}$ \\
\hline $\begin{array}{l}\text { Ok, so can you stand on } \\
\text { one leg, bend your knee, } \\
\text { can you stop your knee } \\
\text { from coming inwards? } \\
\text { And they're like no. Ok, } \\
\text { so you're still standing on } \\
\text { one leg, you're still } \\
\text { bending your knee, but } \\
\text { you're not doing it well. } \\
\text { INT: Yeah. }\end{array}$ & $\begin{array}{l}\text { Rachel provides an example of a } \\
\text { single leg squat as a movement } \\
\text { assessment. She states that if the } \\
\text { patient's knee goes in that they're } \\
\text { not doing it well and then } \\
\text { summarises what was meant by a } \\
\text { movement issue. It seems as though } \\
\text { Rachel is negative in her way to } \\
\text { make patients aware of movement } \\
\text { by repeating the term "you're not". }\end{array}$ & $\begin{array}{l}\text { (Pain?) Education as explaining } \\
\text { the patent's poor movement } \\
\text { Pain education as explaining the } \\
\text { relationship between } \\
\text { mechanical factors contributing } \\
\text { to increased loading and pain }\end{array}$ \\
\hline
\end{tabular}




\begin{tabular}{|c|c|c|}
\hline $\begin{array}{l}\text { Rachel: So that's how, } \\
\text { that's what I mean by } \\
\text { that. }\end{array}$ & $\begin{array}{l}\text { Rachel repeats how a patient not } \\
\text { moving well may contribute to their } \\
\text { pain. Rachel focuses on explaining } \\
\text { to the patient that movement } \\
\text { issues may be causing their pain. }\end{array}$ & \\
\hline $\begin{array}{l}\text { INT: Brilliant, thank you. } \\
\text { And you also mentioned } \\
\text { that sometimes, it may } \\
\text { be like a muscle to brain } \\
\text { issue. What did you } \\
\text { mean by that? }\end{array}$ & $\begin{array}{l}\text { Interviewer asking Rachel to clarify } \\
\text { what was meant by a "muscle to } \\
\text { brain issue". }\end{array}$ & \\
\hline $\begin{array}{l}\text { Rachel: So like um, so } \\
\text { they might not have a } \\
\text { weakness, but their brain } \\
\text { is not connected to their } \\
\text { body basically. }\end{array}$ & $\begin{array}{l}\text { Rachel responds by highlighting } \\
\text { that there might not always be a } \\
\text { weakness but implies that there } \\
\text { may be a separation between brain } \\
\text { and muscle. The repeated term } \\
\text { 'basically' (Is it as simple as that?). }\end{array}$ & $\begin{array}{l}\text { Brain and body separation [to } \\
\text { inform contributing factor to } \\
\text { NSLBP?] }\end{array}$ \\
\hline $\begin{array}{l}\text { So they think they're } \\
\text { doing something. So l'll } \\
\text { say 'right stand on one } \\
\text { leg, put your foot facing } \\
\text { forward.' But they'll put } \\
\text { their foot facing out. } \\
\text { Because that's normal } \\
\text { for them, so their brain } \\
\text { has got, you know that } \\
\text { connection, that's } \\
\text { normal. }\end{array}$ & $\begin{array}{l}\text { Rachel provides an example of } \\
\text { asking a patient to stand one leg } \\
\text { with foot facing forward but patient } \\
\text { may complete task with foot facing } \\
\text { out. For Rachel this occurs because } \\
\text { it's normal for them and their brain } \\
\text { has that connection. }\end{array}$ & Brain and body separation \\
\hline $\begin{array}{l}\text { Or for them to sit } \\
\text { slumped, aw that's } \\
\text { normal posture. I'll say } \\
\text { well no you're meant to } \\
\text { sit like that. 'Aw well that } \\
\text { feels odd.' I'll say yeah } \\
\text { because your body is not } \\
\text { used to that. } \\
\text { INT: Yeah. }\end{array}$ & $\begin{array}{l}\text { Rachel uses another example with } \\
\text { posture and infers how a patient's } \\
\text { posture may not be right and } \\
\text { they're supposed to "sit like that." } \\
\text { She states that this may feel odd for } \\
\text { patients. Is posture being } \\
\text { addressed because it could } \\
\text { contribute to NSLBP? Mechanical } \\
\text { thinking for NSLBP. }\end{array}$ & $\begin{array}{l}\text { Pain education as explaining how } \\
\text { posture may be cause of pain }\end{array}$ \\
\hline $\begin{array}{l}\text { Rachel: So that kind of, } \\
\text { you know brain muscle } \\
\text { connection is kind of that } \\
\text { wiring is out yeah, cus it's } \\
\text { not normal for you to sit } \\
\text { like that so we're going to } \\
\text { do some exercises that } \\
\text { teaches you to sit like } \\
\text { that and we're going to } \\
\text { keep drilling that } \\
\text { exercise so that becomes } \\
\text { a normal behaviour. } \\
\text { INT: Yeah. }\end{array}$ & $\begin{array}{l}\text { Rachel states that exercises will be } \\
\text { completed to address this wiring } \\
\text { issue. } \\
\text { Language almost infers poor } \\
\text { understanding of this "muscle to } \\
\text { brain connection" (repeated "kind } \\
\text { of" and "you know") } \\
\text { There seems to be an increased } \\
\text { effort to improve posture as if it is } \\
\text { so important to sit in a certain way. } \\
\text { ?No shared decision making; "we're } \\
\text { going to do" }\end{array}$ & $\begin{array}{l}\text { Pain education as explaining how } \\
\text { exercises may help with posture } \\
\text { and NSLBP } \\
\text { Pain education as explaining } \\
\text { [brain muscle connection] as a } \\
\text { contributing factor to pain }\end{array}$ \\
\hline
\end{tabular}




\begin{tabular}{|c|c|c|}
\hline $\begin{array}{l}\text { Rachel: So, it's like a habit } \\
\text { basically. }\end{array}$ & & \\
\hline $\begin{array}{l}\text { INT: Brilliant, and do you } \\
\text { have any other examples } \\
\text { where you have gone } \\
\text { through and maybe } \\
\text { provided some pain } \\
\text { education with a patient } \\
\text { with non-specific low } \\
\text { back pain. }\end{array}$ & $\begin{array}{l}\text { Interviewer is asking Rachel to talk } \\
\text { through another example for } \\
\text { further insight into the } \\
\text { phenomenon. }\end{array}$ & \\
\hline $\begin{array}{l}\text { Rachel: What like in an } \\
\text { assessment or? } \\
\text { INT: Anything at all, um } \\
\text { just an experience where } \\
\text { you have been with a } \\
\text { patient and yeah, we } \\
\text { could talk through that } \\
\text { entire situation if you } \\
\text { want. So it might start } \\
\text { from the assessment um } \\
\text { and then to get more an } \\
\text { understanding, we could } \\
\text { try and talk through just } \\
\text { like you did there, start to } \\
\text { finish. Can you think of } \\
\text { any cases? } \\
\text { Rachel: So a different } \\
\text { patient or? } \\
\text { INT: Yeah. }\end{array}$ & $\begin{array}{l}\text { Rachel replies with a question "like } \\
\text { an assessment?" The interviewer } \\
\text { replies and elaborates that the } \\
\text { entire situation with a patient could } \\
\text { be discussed. The interviewer also } \\
\text { makes Rachel aware that this would } \\
\text { be for another patient. } \\
\text { It is almost as though she didn't } \\
\text { understand or comprehend the } \\
\text { question. The impression is she } \\
\text { doesn't understand what the } \\
\text { interviewer means by 'providing } \\
\text { pain education?' }\end{array}$ & $\begin{array}{l}\text { Assumption of physiotherapist's } \\
\text { lack of understanding of pain } \\
\text { education }\end{array}$ \\
\hline $\begin{array}{l}\text { Rachel: A different } \\
\text { patient. Um, I'm just } \\
\text { trying to think. I kind of } \\
\text { pretty much do it the } \\
\text { same way. } \\
\text { INT: That's fine. }\end{array}$ & $\begin{array}{l}\text { Rachel informs the interviewer that } \\
\text { she "pretty much does it the same } \\
\text { way." What does Rachel mean by } \\
\text { it? Mechanical assessment and } \\
\text { mechanical exercise? }\end{array}$ & $\begin{array}{l}\text { Pain education appears to be } \\
\text { similar with each patient }\end{array}$ \\
\hline $\begin{array}{l}\text { Rachel: With most } \\
\text { patients. Depending, for } \\
\text { me it always comes down } \\
\text { to how someone moves. } \\
\text { INT: Yeah. }\end{array}$ & $\begin{array}{l}\text { Rachel states that it "always comes } \\
\text { down to how someone moves." Is } \\
\text { the term "most patients" indicating } \\
\text { that Rachel stereotypes or } \\
\text { generalises many patients with } \\
\text { NSLBP? It seems that the patients } \\
\text { focus is on how someone moves. Is } \\
\text { pain education based on movement } \\
\text { dysfunction? As Rachel feels that } \\
\text { the way someone moves is what } \\
\text { NSLBP 'comes down to' is this } \\
\text { reflecting her lack of understanding } \\
\text { of the complex nature of NSLBP? }\end{array}$ & 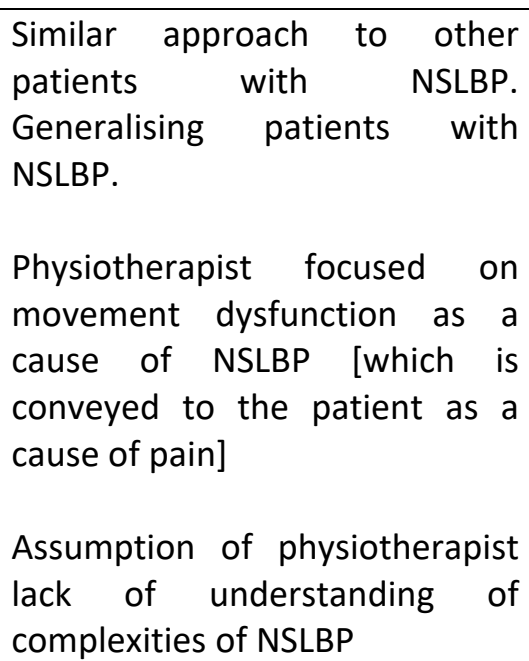 \\
\hline
\end{tabular}




\begin{tabular}{|c|c|c|}
\hline $\begin{array}{l}\text { Rachel: Like so, if they } \\
\text { come in and they're like, } \\
\text { yeah you can have a } \\
\text { massage but it's not } \\
\text { going to change your } \\
\text { back pain because you do } \\
x, y \text { and z. } \\
\text { INT: Yeah. }\end{array}$ & $\begin{array}{l}\text { For Rachel it seems as though she } \\
\text { will provide massage as the } \\
\text { treatment desires it? But she } \\
\text { acknowledges that this may not } \\
\text { influence the pain because of the } \\
\text { patient actions ("doing } x, y \text { and } z^{\prime \prime} \text { ) } \\
\text { Are the patients actions the only } \\
\text { reason for NSLBP? Is this indicating } \\
\text { blame to the patient? It seems as } \\
\text { though Rachel is not addressing } \\
\text { what else could be contributing to } \\
\text { pain (biopsychosocial factors) }\end{array}$ & $\begin{array}{l}\text { Manual therapy not helpful } \\
\text { because of other contributing } \\
\text { factors (mechanical?) } \\
\text { Pain education as explaining } \\
\text { patient's actions contributing to } \\
\text { NSLBP } \\
\text { Assumption of physiotherapist } \\
\text { not addressing biopsychosocial } \\
\text { factors of NSLBP } \\
\text { Pain education as addressing } \\
\text { other contributing factors } \\
\text { (patient's actions) }\end{array}$ \\
\hline $\begin{array}{l}\text { Rachel: You know. And } \\
\text { it's generally, yeah you } \\
\text { don't sit well, you don't } \\
\text { stand well, you don't run } \\
\text { well or you know you } \\
\text { don't do something well. }\end{array}$ & $\begin{array}{l}\text { For Rachel it seems that "generally" } \\
\text { NSLBP is because of mechanical } \\
\text { factors such as not standing or } \\
\text { sitting well. Repeated "don't" } \\
\text { negative terminology, is this } \\
\text { reflecting how she approaches } \\
\text { communication with patients with } \\
\text { NSLBP? }\end{array}$ & $\begin{array}{l}\text { Pain education as explaining the } \\
\text { mechanical factors contributing } \\
\text { (causing) NSLBP? } \\
\text { Generalising patients with NSLBP }\end{array}$ \\
\hline $\begin{array}{l}\text { Then it's finding out that } \\
\text { reason. So I always kind } \\
\text { of approach it like that. I } \\
\text { mean the reasons might } \\
\text { be different for each } \\
\text { person. } \\
\text { INT: Yeah. }\end{array}$ & $\begin{array}{l}\text { Rachel admits that she will always } \\
\text { approach NSLBP in a similar way } \\
\text { seeing to find out the contributing } \\
\text { factors for NSLBP. (Largely } \\
\text { mechanical?) }\end{array}$ & $\begin{array}{l}\text { Importance of assessment to } \\
\text { establish reason for pain } \\
\text { contributing factors } \\
\text { Similar approach to NSLBP } \\
\text { management for each patient }\end{array}$ \\
\hline $\begin{array}{l}\text { Rachel: Yeah, I would say } \\
\text { it's the same. I would } \\
\text { handle it the same way. }\end{array}$ & $\begin{array}{l}\text { Rachel confirms that she would } \\
\text { approach each patient in the } \\
\text { "same" way. Is handling referring to } \\
\text { a problem which Rachel needs to } \\
\text { overcome? Is this terminology } \\
\text { referring to a task which she would } \\
\text { have had to have full control over? }\end{array}$ & $\begin{array}{l}\text { Pain education similar for each } \\
\text { patient } \\
\text { Taking control over the patient } \\
\text { encounter with NSLBP }\end{array}$ \\
\hline $\begin{array}{l}\text { INT: Yeah, that's } \\
\text { absolutely fine. Um, and } \\
\text { although you may handle } \\
\text { it the same way, can we } \\
\text { still talk through a } \\
\text { situation, just so I can get } \\
\text { an understanding about. } \\
\text { Rachel: Ok. Just trying to } \\
\text { think who we have got. } \\
\text { Um. } \\
\text { INT: That's ok, take your } \\
\text { time. }\end{array}$ & $\begin{array}{l}\text { The interviewer asks if Rachel } \\
\text { wouldn't mind talking through a } \\
\text { situation even though Rachel may } \\
\text { handle it in the same way. }\end{array}$ & \\
\hline
\end{tabular}




\begin{tabular}{|c|c|c|}
\hline $\begin{array}{l}\text { Rachel: Yeah he's } \\
\text { another one, but I would } \\
\text { have handled that the } \\
\text { same. } \\
\text { INT: Ok that's fine. } \\
\text { Rachel: Is that alright? } \\
\text { INT: Yeah, yeah. So if we } \\
\text { can just talk through that } \\
\text { experience, just talk } \\
\text { through your actions in } \\
\text { as much detail as } \\
\text { possible. }\end{array}$ & $\begin{array}{l}\text { Rachel thinks of another patient to } \\
\text { discuss and states that she would } \\
\text { have "handled" it the same. Again, } \\
\text { is this terminology referring to a } \\
\text { task which she would have had to } \\
\text { have full control over? Seems as } \\
\text { though if Rachel is handling the } \\
\text { case, the patient may have not been } \\
\text { very involved in the decision } \\
\text { making? }\end{array}$ & $\begin{array}{l}\text { Pain education as being handled } \\
\text { Taking control over the patient } \\
\text { encounter with NSLBP } \\
\text { Same approach to each patient } \\
\text { with NSLBP }\end{array}$ \\
\hline $\begin{array}{l}\text { Rachel: So, um he's had } \\
\text { low back pain since like } \\
41 . \\
\text { INT: Ok. } \\
\text { Rachel: He had low back } \\
\text { pain for ten years. } \\
\text { INT: Wow, ok. }\end{array}$ & $\begin{array}{l}\text { Rachel begins to describe the } \\
\text { patient and states that the patient } \\
\text { is } 41 \text { and has had chronic low back } \\
\text { pain for } 10 \text { years. }\end{array}$ & \\
\hline $\begin{array}{l}\text { Rachel: Um and football } \\
\text { used to aggravate his } \\
\text { back. Um, and then he } \\
\text { just gets a bit stiff in his } \\
\text { lower back. } \\
\text { INT: } \mathrm{mm} \text {. }\end{array}$ & $\begin{array}{l}\text { Rachel outlines that football } \\
\text { aggravated the patient's back } \\
\text { previously and now he "just gets a } \\
\text { bit stiff in his lower back." Sporting } \\
\text { activities contributing to NSLBP. }\end{array}$ & $\begin{array}{l}\text { Sporting activities contributing } \\
\text { to NSLBP } \\
\text { Mechanical problems (stiffness) }\end{array}$ \\
\hline $\begin{array}{l}\text { Rachel: Um, but no, he's } \\
\text { had no injury to his back } \\
\text { at all. It's just kind of, } \\
\text { yeah, you know time. }\end{array}$ & $\begin{array}{l}\text { had not sustained an injury } \\
\text { ck. }\end{array}$ & $\begin{array}{l}\text { NSLBP not necessarily related to } \\
\text { injury }\end{array}$ \\
\hline $\begin{array}{l}\text { Um, generally things that } \\
\text { aggravate it are kind of } \\
\text { like sitting, anything that } \\
\text { uses his back. Walking a } \\
\text { long time, gardening, } \\
\text { sort of bending activities. }\end{array}$ & $\begin{array}{l}\text { Rachel lists the activities which now } \\
\text { aggravate his back which include } \\
\text { sitting, prolonged walking, } \\
\text { gardening and bending. Seems that } \\
\text { all activities would aggravate the } \\
\text { NSLBP? ("anything that uses the } \\
\text { back") }\end{array}$ & $\begin{array}{l}\text { Movement aggravating back } \\
\text { Mechanical factors aggravating } \\
\text { NSLBP }\end{array}$ \\
\hline $\begin{array}{l}\text { Um, in assessment, yeah } \\
\text { he moved quite well in } \\
\text { his back. Um, little bit } \\
\text { tight, and it was just kind } \\
\text { of glute pain really. } \\
\text { Nothing real specific. }\end{array}$ & $\begin{array}{l}\text { Rachel assessed movement. Found } \\
\text { tightness and glute pain. } \\
\text { Does "Just kind of" imply that it is } \\
\text { nothing too serious? }\end{array}$ & $\begin{array}{l}\text { Use of assessments to explore } \\
\text { movement as a potential cause } \\
\text { for NSLBP [to inform pain } \\
\text { education regarding the cause of } \\
\text { NSLBP] }\end{array}$ \\
\hline $\begin{array}{l}\text { There wasn't you know, } \\
\text { no neurological } \\
\text { problems, he had general } \\
\text { kind of good strength. } \\
\text { Um, good range of } \\
\text { movement and just } \\
\text { didn't move very well } \\
\text { basically. }\end{array}$ & $\begin{array}{l}\text { During explanation of the } \\
\text { assessment it seems that } \\
\text { neurological problems in addition } \\
\text { to mechanical factors were } \\
\text { considered including strength, } \\
\text { range of movement and } \\
\text { movement. } \\
\text { Contradiction to previous comment } \\
\text { that "patient moved well?" }\end{array}$ & $\begin{array}{l}\text { Use of assessments to explore } \\
\text { movement as a potential cause } \\
\text { for NSLBP [to inform pain } \\
\text { education regarding the cause of } \\
\text { NSLBP] } \\
\text { Physiotherapist focused on } \\
\text { movement dysfunction as a } \\
\text { cause of NSLBP }\end{array}$ \\
\hline
\end{tabular}




\begin{tabular}{|c|c|c|}
\hline $\begin{array}{l}\text { So, he wanted to get back } \\
\text { to the gym. He was } \\
\text { another squat person, } \\
\text { couldn't squat. }\end{array}$ & $\begin{array}{l}\text { Patient wanted to get back to the } \\
\text { gym. Rachel states that the patient } \\
\text { couldn't squat, Is this because of a } \\
\text { technical issue or pain? }\end{array}$ & \\
\hline $\begin{array}{l}\text { Um, he would squat and } \\
\text { his pelvis, like lumbar } \\
\text { pelvic control, just like } \\
\text { yeah, just didn't know, } \\
\text { he didn't know where it } \\
\text { was. It was like flexing his } \\
\text { back and then he was } \\
\text { arching his back, }\end{array}$ & $\begin{array}{l}\text { Rachel explains that when the } \\
\text { patient squatted, he had reduced } \\
\text { lumbar pelvic control. Use of squat } \\
\text { as an assessment. Focus on } \\
\text { mechanical dysfunction? }\end{array}$ & $\begin{array}{l}\text { Assessment (squatting) to } \\
\text { inform contributing pain factors } \\
\text { [largely mechanical] }\end{array}$ \\
\hline $\begin{array}{l}\text { um, so I obviously did } \\
\text { some soft tissue stuff, }\end{array}$ & $\begin{array}{l}\text { Rachel implies that "soft tissue } \\
\text { stuff" is something which is always } \\
\text { done? Why is this always done? Is it } \\
\text { an obligation? Does Rachel believe } \\
\text { there are specific benefits? }\end{array}$ & $\begin{array}{l}\text { "Soft tissue" treatment } \\
\text { essential? [in addition to pain } \\
\text { education?] }\end{array}$ \\
\hline $\begin{array}{l}\text { explained that there } \\
\text { wasn't really anything } \\
\text { wrong with his back, he } \\
\text { could have a scan and it } \\
\text { wouldn't probably show } \\
\text { anything, hes only } 40 . \\
\text { INT: mm.. }\end{array}$ & $\begin{array}{l}\text { Rachel reassured the patient that } \\
\text { "there wasn't really anything wrong } \\
\text { with the back." Explained that the } \\
\text { scan wouldn't show anything but no } \\
\text { explanation of source of } \\
\text { symptoms? }\end{array}$ & $\begin{array}{l}\text { Pain education as [explaining } \\
\text { diagnosis] reassuring patient } \\
\text { nothing wrong with back } \\
\text { Pain education as highlighting } \\
\text { negative correlation between } \\
\text { imaging and pain }\end{array}$ \\
\hline $\begin{array}{l}\text { Rachel: Umm, you know } \\
\text { might have some age } \\
\text { related degenerative } \\
\text { changes, but it probably } \\
\text { wouldn't pick up that, } \\
\text { and it was just normal, } \\
\text { normal lumbar spine. } \\
\text { INT: mm } \\
\text { Rachel: Umm, and that } \\
\text { he was just literately, } \\
\text { loading structures in his } \\
\text { back because he wasn't } \\
\text { moving very well. }\end{array}$ & $\begin{array}{l}\text { Rachel explains that NSLBP in this } \\
\text { case was literately due to increased } \\
\text { loading of structures because the } \\
\text { patient was not moving very well. } \\
\text { Structures are being loaded due to } \\
\text { poor quality movement. There } \\
\text { seems to be a focus on mechanical } \\
\text { issues and a large focus on } \\
\text { movement quality. The terminology } \\
\text { "just literately" almost indicates } \\
\text { that this is solely down to the poor } \\
\text { movement for Rachel. }\end{array}$ & $\begin{array}{l}\text { Pain education as highlighting } \\
\text { increased mechanical factors } \\
\text { causing pain } \\
\text { Pain education as reassuring } \\
\text { patient about diagnosis }\end{array}$ \\
\hline $\begin{array}{l}\text { So, then I explained, } \\
\text { what movement was, } \\
\text { filmed him doing certain } \\
\text { things that would cause }\end{array}$ & $\begin{array}{l}\text { Rachel explained what movement } \\
\text { was and then video recorded the } \\
\text { patient completing things which } \\
\text { would cause pain and then Rachel }\end{array}$ & $\begin{array}{l}\text { Pain education as highlighting } \\
\text { poor movement which may be } \\
\text { contributing to pain? }\end{array}$ \\
\hline
\end{tabular}




\begin{tabular}{|c|c|c|}
\hline $\begin{array}{l}\text { his back pain and then } \\
\text { pointed out what was } \\
\text { wrong. }\end{array}$ & $\begin{array}{l}\text { pointed out what was wrong. For } \\
\text { Rachel it seems that an } \\
\text { improvement in movement would } \\
\text { result in improved pain. Use of } \\
\text { video to facilitate mechanical } \\
\text { assessment. }\end{array}$ & \\
\hline $\begin{array}{l}\text { And then corrected his } \\
\text { technique, so I would } \\
\text { show him and then I } \\
\text { would get him moving. }\end{array}$ & $\begin{array}{l}\text { Rachel corrected the patient's } \\
\text { technique but provided a } \\
\text { demonstration first? Focus on } \\
\text { improving movement technique. }\end{array}$ & $\begin{array}{l}\text { Improving movement technique } \\
\text { to assist with pain }\end{array}$ \\
\hline $\begin{array}{l}\text { I might have done a few } \\
\text { different exercises to } \\
\text { explain to him what } \\
\text { normal lumbar-pelvic } \\
\text { control was. I would have } \\
\text { chosen a few exercises } \\
\text { that may have been } \\
\text { challenging for him. }\end{array}$ & $\begin{array}{l}\text { Rachel might have gone through } \\
\text { some exercises which would have } \\
\text { been challenging toe the patient to } \\
\text { explain what normal lumbar pelvic } \\
\text { control was. Rachel's explanations } \\
\text { have been focused on movement } \\
\text { and mechanics of the back. Why did } \\
\text { Rachel chose challenging exercises? } \\
\text { Does the use of core stability } \\
\text { exercises reflect the } \\
\text { physiotherapists mechanical focus } \\
\text { of NSLBP and lack of understanding } \\
\text { or contemporary evidence? }\end{array}$ & $\begin{array}{l}\text { [Pain education as] teaching } \\
\text { patient about normal lumbar- } \\
\text { pelvic control [to assist with } \\
\text { pain?] } \\
\text { Assumption of physiotherapists } \\
\text { lack of knowledge of } \\
\text { contemporary evidence }\end{array}$ \\
\hline $\begin{array}{l}\text { Umm, that challenged } \\
\text { say if he was arching his } \\
\text { back or flexing, I would } \\
\text { have chosen an exercise } \\
\text { that made him do that } \\
\text { and then he would had to } \\
\text { of um control that and } \\
\text { stop that from } \\
\text { happening. } \\
\text { INT: mm.. }\end{array}$ & $\begin{array}{l}\text { Rachel elaborates that the exercises } \\
\text { would have made the patient arch } \\
\text { his back for example to facilitate } \\
\text { control of that position (however } \\
\text { Rachel talking in rhetoric's "would } \\
\text { have"). Focus on stability of lower } \\
\text { back }\end{array}$ & Focus on stability of lower back \\
\hline $\begin{array}{l}\text { Rachel: Umm, } \\
\text { INT: Can you remember } \\
\text { what that exercise was } \\
\text { and what you did? }\end{array}$ & $\begin{array}{l}\text { Interviewer asks Rachel if she can } \\
\text { remember what the exercise was. }\end{array}$ & \\
\hline $\begin{array}{l}\text { Rachel: What would I } \\
\text { have done for him? Um, } \\
\text { so he, so one of the tests } \\
\text { that I would have looked } \\
\text { at for him would have } \\
\text { been lying on his back, } \\
\text { um, we would have used } \\
\text { the PBU. } \\
\text { INT: Yeah. }\end{array}$ & $\begin{array}{l}\text { Rachel indicates that another } \\
\text { assessment would have been the } \\
\text { use of the PBU (pressure bio- } \\
\text { feedback unit). Assessment of core } \\
\text { stability. Rachel is continuing to } \\
\text { explore the mechanical factors } \\
\text { which may be contributing to } \\
\text { NSLBP. }\end{array}$ & $\begin{array}{l}\text { Core stability assessment for } \\
\text { NSLBP [to explore the } \\
\text { mechanical factors which may be } \\
\text { contributing to NSLBP] }\end{array}$ \\
\hline $\begin{array}{l}\text { Rachel: Um and then he } \\
\text { would have, you have to } \\
\text { bring both legs up, } \\
\text { keeping your pelvis at } \\
\text { neutral which is } 40 \text { on the }\end{array}$ & $\begin{array}{l}\text { Rachel explains what was required } \\
\text { of the assessment with the PBU. } \\
\text { Rachel explained the movement } \\
\text { 'errors' the patient was doing } \\
\text { during the assessment. }\end{array}$ & Focus on mechanical dysfunction \\
\hline
\end{tabular}




\begin{tabular}{|c|c|c|}
\hline $\begin{array}{l}\text { PBU. Um, so what he did } \\
\text { is when he brought his } \\
\text { legs up, he flexed his } \\
\text { back, when he dropped } \\
\text { his legs he arched his } \\
\text { back. } \\
\text { INT: Ok. }\end{array}$ & & \\
\hline $\begin{array}{l}\text { INT: Ok. } \\
\text { Rachel: So I said to him, } \\
\text { right 'think about your } \\
\text { pelvis as like a bucket, if } \\
\text { you bring it forward, you } \\
\text { tip out the water, if you } \\
\text { bring it back you fill it up.' } \\
\text { INT: Yeah. }\end{array}$ & $\begin{array}{l}\text { Rachel used an analogy to make it } \\
\text { easier for the patient to } \\
\text { understand. } \\
\text { Focus on bodies mechanics (pelvis). }\end{array}$ & $\begin{array}{l}\text { Use of analogy to assist with core } \\
\text { stability [to help reduce pain?] }\end{array}$ \\
\hline $\begin{array}{l}\text { Rachel: I said keep it at } \\
\text { neutral, make sure that } \\
\text { water doesn't fill, um, } \\
\text { spill out or I sometimes } \\
\text { use like a spirit level and } \\
\text { I'm like keep that little } \\
\text { bubble in the middle. } \\
\text { INT: Yeah, nice. }\end{array}$ & $\begin{array}{l}\text { Rachel explains how she continues } \\
\text { to use an analogy of a bucket with } \\
\text { water or a spirit level to assist with } \\
\text { the exercise. } \\
\text { Analogy to facilitate understanding }\end{array}$ & $\begin{array}{l}\text { Analogy to facilitate } \\
\text { understanding }\end{array}$ \\
\hline $\begin{array}{l}\text { Rachel: Keep that PBU at } \\
40 \text {, um so lots of visual } \\
\text { ques as well. }\end{array}$ & $\begin{array}{l}\text { Rachel utilises the PBU to provide } \\
\text { visual feedback for the patient. }\end{array}$ & Visual feedback of exercise \\
\hline $\begin{array}{l}\text { Um, and then explain to } \\
\text { him about what muscles } \\
\text { to kind of activate, got } \\
\text { them sort of activated } \\
\text { and I said keep that it at } \\
40 \text {. }\end{array}$ & $\begin{array}{l}\text { Rachel continues to focus on } \\
\text { mechanics and explains to the } \\
\text { patient what muscles to focus on } \\
\text { activating. Rachel uses terms such } \\
\text { as "kind of" and "sort of". Does this } \\
\text { indicate a potential lack of } \\
\text { understanding or belief in what she } \\
\text { is doing? Anatomy explanation. }\end{array}$ & $\begin{array}{l}\text { [Pain education as] explaining } \\
\text { about activation of muscles to } \\
\text { help with posture } \\
\text { Lack of understanding/belief in } \\
\text { treatment? }\end{array}$ \\
\hline $\begin{array}{l}\text { And then it was literately } \\
\text { drop a leg, bring it back } \\
\text { up, drop the other leg, } \\
\text { bring it back up, keeping } \\
\text { at } 40 \text {. } \\
\text { INT: Brilliant. }\end{array}$ & $\begin{array}{l}\text { Rachel explains the exercise in more } \\
\text { detail. }\end{array}$ & \\
\hline $\begin{array}{l}\text { Rachel: So then he had to } \\
\text { kind of understand, like } \\
\text { keeping something still } \\
\text { whilst moving something } \\
\text { else. Um, so he is not } \\
\text { moving through his back. }\end{array}$ & $\begin{array}{l}\text { Rachel explains that the focus was } \\
\text { to keep the back still when } \\
\text { completing other movement. "kind } \\
\text { of" - full understanding not } \\
\text { required? Is this not encouraging } \\
\text { immobility of the back which may } \\
\text { influence NSLBP? }\end{array}$ & $\begin{array}{l}\text { Pain education as improving } \\
\text { understanding of lower back } \\
\text { stability }\end{array}$ \\
\hline
\end{tabular}




\begin{tabular}{|c|c|c|}
\hline $\begin{array}{l}\text { Um, and another one I } \\
\text { would have done, would } \\
\text { have been a bridge } \\
\text { exercise. So you lift up, } \\
\text { um then you just } \\
\text { straighten one leg, put } \\
\text { the leg down, straighten } \\
\text { the other leg and then if } \\
\text { the pelvis, like the } \\
\text { bottom drops, l'll say } \\
\text { 'don't let your bottom } \\
\text { drop, squeeze your } \\
\text { glutes.' } \\
\text { INT: Mm.. }\end{array}$ & $\begin{array}{l}\text { Rachel elaborates on the bridging } \\
\text { exercise, focus on the pelvis and } \\
\text { glute activation during this exercise }\end{array}$ & $\begin{array}{l}\text { Focus on pelvis and glute } \\
\text { activation }\end{array}$ \\
\hline $\begin{array}{l}\text { Rachel: And if they're like } \\
\text { I don't really know what } \\
\text { you mean I was like put } \\
\text { your hands on you know } \\
\text { your hips and see } \\
\text { whether they drop. }\end{array}$ & $\begin{array}{l}\text { For Rachel it seems as though } \\
\text { patients may not understand the } \\
\text { exercise. She then instructs the } \\
\text { patient to place their hands on their } \\
\text { hips to help feedback. Focus on } \\
\text { preventing hips from dropping - } \\
\text { focus on pelvis. }\end{array}$ & Use of pelvis stability exercise \\
\hline $\begin{array}{l}\text { Umm, so then he would } \\
\text { have had to yeah, sort of } \\
\text { feel you know what was } \\
\text { happening through the } \\
\text { lumbar spine. }\end{array}$ & $\begin{array}{l}\text { Rachel implies that this would have } \\
\text { helped to "feel" what was going on } \\
\text { through the lumbar spine. }\end{array}$ & Focus on lumbar spine position \\
\hline $\begin{array}{l}\text { I would have got him sort } \\
\text { of doing that, queuing } \\
\text { quite a lot and then } \\
\text { looking at those } \\
\text { exercises that he } \\
\text { struggled with. }\end{array}$ & $\begin{array}{l}\text { Rachel summarises that she would } \\
\text { have done the exercises, used } \\
\text { queuing and would have looked at } \\
\text { exercises that the patient struggles } \\
\text { with. Rachel is talking in rhetoric's } \\
\text { again, can she not remember the } \\
\text { experience or is not speaking the } \\
\text { truth? }\end{array}$ & \\
\hline $\begin{array}{l}\text { And then maybe then } \\
\text { progressing it to a more } \\
\text { standing up position. } \\
\text { Um, yeah that's what I } \\
\text { would have done for him. }\end{array}$ & $\begin{array}{l}\text { Rachel would progress the } \\
\text { exercises. }\end{array}$ & Exercise progression \\
\hline $\begin{array}{l}\text { INT: Brilliant. You } \\
\text { mentioned that you } \\
\text { explained to him what } \\
\text { movement was. Can you } \\
\text { elaborate a little bit on } \\
\text { that please? }\end{array}$ & $\begin{array}{l}\text { Interviewer asks Rachel to } \\
\text { elaborate what was meant by } \\
\text { explaining what movement was. }\end{array}$ & \\
\hline $\begin{array}{l}\text { Rachel: Ok, movement } \\
\text { being that um, so when } \\
\text { we move, we need to } \\
\text { move in the right way. } \\
\text { INT: mm.. }\end{array}$ & $\begin{array}{l}\text { For Rachel it seems its very } \\
\text { important to move in the right way. }\end{array}$ & $\begin{array}{l}\text { Pain education as highlighting } \\
\text { importance } \\
\text { movement. }\end{array}$ \\
\hline
\end{tabular}




\begin{tabular}{|c|c|c|}
\hline $\begin{array}{l}\text { Rachel: So like, } \\
\text { sometimes I use like car, } \\
\text { like tracking on the car, }\end{array}$ & $\begin{array}{l}\text { Rachel uses the car analogy to } \\
\text { explain movement. }\end{array}$ & $\begin{array}{l}\text { Pain education as using (car) } \\
\text { analogy to highlight correct } \\
\text { movement }\end{array}$ \\
\hline $\begin{array}{l}\text { So l'll say like if your } \\
\text { tracking is out so if you go } \\
\text { over a curb and you just } \\
\text { tap that wheel and the } \\
\text { wheel kinda changes you } \\
\text { know kind of moves } \\
\text { around. And then you're } \\
\text { driving around for a } \\
\text { period of time and then } \\
\text { your tyre starts to wear } \\
\text { on one side or your brake } \\
\text { pads are starting to go. } \\
\text { Your tracking is out. }\end{array}$ & $\begin{array}{l}\text { Comparing the patient's moving to } \\
\text { misaligned tracking of the car. } \\
\text { Indicating imbalances? }\end{array}$ & $\begin{array}{l}\text { Pain education as using (car) } \\
\text { analogy to explain correct } \\
\text { movement }\end{array}$ \\
\hline $\begin{array}{l}\text { So same with the body so } \\
\text { if you're like, every time } \\
\text { you move, through your } \\
\text { back, say they go and } \\
\text { pick something up and } \\
\text { you're moving just } \\
\text { through your back and } \\
\text { not from your hips and } \\
\text { your knees where you } \\
\text { should be moving then } \\
\text { you're loading the back. } \\
\text { INT: mm.. }\end{array}$ & $\begin{array}{l}\text { Rachel states that the patient } \\
\text { should not move through the back } \\
\text { when they pick something up and } \\
\text { states that the movement should } \\
\text { come from the hips and knees or } \\
\text { the patient is loading their back. } \\
\text { This understanding seems to } \\
\text { contradict literature and in fact } \\
\text { Rachel is encouraging reduced } \\
\text { movement and increased } \\
\text { awareness of back. Is this because } \\
\text { Rachel is concerned about the } \\
\text { back? Does she not feel the back is } \\
\text { as strong as it is? Does Rachel have } \\
\text { negative health beliefs? }\end{array}$ & $\begin{array}{l}\text { Pain education as explaining } \\
\text { about movement to prevent } \\
\text { loading [cause of NSLBP?] } \\
\text { Assumption of physiotherapists } \\
\text { lack of understanding of } \\
\text { contemporary evidence } \\
\text { Assumption of physiotherapist } \\
\text { negative beliefs about the back }\end{array}$ \\
\hline $\begin{array}{l}\text { Rachel: So your } \\
\text { movement, that's not } \\
\text { good quality movement. }\end{array}$ & $\begin{array}{l}\text { Further explains to the patient that, } \\
\text { that is not good movement. } \\
\text { Negative in communication } \\
\text { (repetition of "not") }\end{array}$ & $\begin{array}{l}\text { Pain education as highlighting } \\
\text { poor quality movement [as a } \\
\text { potential cause or contributing } \\
\text { factor to NSLBP] }\end{array}$ \\
\hline $\begin{array}{l}\text { INT: I like that analogy. } \\
\text { Rachel: Yeah, so I would } \\
\text { say, yeah. It works well } \\
\text { with the guys because } \\
\text { they understand the car. }\end{array}$ & $\begin{array}{l}\text { Rachel likes to use analogies which } \\
\text { she thinks participants will } \\
\text { understand. }\end{array}$ & $\begin{array}{l}\text { Analogies to improve } \\
\text { understanding of NSLBP }\end{array}$ \\
\hline $\begin{array}{l}\text { So yeah, we're looking at } \\
\text { quality movement, so we } \\
\text { can all move but how } \\
\text { well do we move? And } \\
\text { what does that, you } \\
\text { know poor movement } \\
\text { mean to the body. } \\
\text { INT: mm.. }\end{array}$ & $\begin{array}{l}\text { Rachel repeats that she looks at } \\
\text { quality of movement and implies } \\
\text { that poor movement may have } \\
\text { implications to the body. }\end{array}$ & $\begin{array}{l}\text { Pain education as explaining how } \\
\text { poor movement may contribute } \\
\text { to NSLBP? }\end{array}$ \\
\hline
\end{tabular}




\begin{tabular}{|c|c|c|}
\hline $\begin{array}{l}\text { Rachel: Basically we start } \\
\text { loading our joints, or our } \\
\text { tendons or our muscles } \\
\text { and that's why we get } \\
\text { pain. }\end{array}$ & $\begin{array}{l}\text { She elaborates that poor } \\
\text { movement may result in increased } \\
\text { loading of joints, tendons or } \\
\text { muscles and that is the reason for } \\
\text { pain. For Rachel it seems that NSLBP } \\
\text { seems to be predominantly caused } \\
\text { by a movement issue and } \\
\text { anatomical structures become } \\
\text { painful because of this. Biomedical } \\
\text { approach }\end{array}$ & $\begin{array}{l}\text { Pain education as highlighting } \\
\text { poor movement results in } \\
\text { increased loading as a cause of } \\
\text { pain }\end{array}$ \\
\hline $\begin{array}{l}\text { INT: Brilliant. } \\
\text { Rachel: Rather than just } \\
\text { being, we've talked, kind } \\
\text { of talked a bit technical } \\
\text { you know. 'your lumbar } \\
\text { spine doesn't flex.' Or } \\
\text { 'anterior or posterior } \\
\text { tilt.' They don't get that. } \\
\text { INT: Yeah. }\end{array}$ & $\begin{array}{l}\text { Rachel acknowledges that patients } \\
\text { may not understand physiotherapy } \\
\text { jargon. Modification of language to } \\
\text { improve understanding? }\end{array}$ & $\begin{array}{l}\text { Modification of language to } \\
\text { improve understanding? [during } \\
\text { pain education] }\end{array}$ \\
\hline $\begin{array}{l}\text { Rachel: So if you think } \\
\text { about something that } \\
\text { they do every day or } \\
\text { relates to their job, then } \\
\text { they tend to understand } \\
\text { it a little bit. }\end{array}$ & $\begin{array}{l}\text { When explaining and using analogy } \\
\text { Rachel attempts to make it relate to } \\
\text { the patient. }\end{array}$ & $\begin{array}{l}\text { Modification of language to } \\
\text { improve understanding }\end{array}$ \\
\hline $\begin{array}{l}\text { INT: Yeah like driving the } \\
\text { car. } \\
\text { Rachel: Yeah like driving } \\
\text { the car, not hitting the } \\
\text { curb. }\end{array}$ & $\begin{array}{l}\text { Interviewer summaries previous } \\
\text { comments by highlighting the car } \\
\text { analogy as an example. }\end{array}$ & \\
\hline $\begin{array}{l}\text { INT: And with that } \\
\text { patient there, did you } \\
\text { talk to him about his pain } \\
\text { at all? } \\
\text { Rachel: His pain? } \\
\text { INT: Yeah. }\end{array}$ & $\begin{array}{l}\text { Interviewers asks Rachel if she } \\
\text { spoke about the patient pain much } \\
\text { as thus far it seems much of the } \\
\text { conversation and explanations } \\
\text { wereregarding } \\
\text { mechanical/movement issues and } \\
\text { subsequent exercises to address } \\
\text { this. }\end{array}$ & \\
\hline $\begin{array}{l}\text { Rachel: Yeah um so, in } \\
\text { the first session we talk } \\
\text { about pain in terms of } \\
\text { like he was getting quite } \\
\text { stiff in his back. }\end{array}$ & $\begin{array}{l}\text { Pain was discussed directly related } \\
\text { to stiffness. } \\
\text { Narrowed discussion of pain } \\
\text { directly related to stiffness }\end{array}$ & $\begin{array}{l}\text { Pain communication focus on } \\
\text { source of symptoms }\end{array}$ \\
\hline $\begin{array}{l}\text { And I said it wasn't } \\
\text { necessarily you know any } \\
\text { particular structure it's } \\
\text { probably you know jointy } \\
\text { and muscles getting tight } \\
\text { as well. }\end{array}$ & $\begin{array}{l}\text { It seems that Rachel does may have } \\
\text { had some suspicion that the pain } \\
\text { was more complex than she was } \\
\text { describing and seems unsure of } \\
\text { exactly why patient was getting } \\
\text { pain. However she implies that it } \\
\text { was probably due to structural } \\
\text { issues such as tight muscles. The }\end{array}$ & $\begin{array}{l}\text { Pain education as not focused on } \\
\text { structure? } \\
\text { Pain education explaining that } \\
\text { tight muscles are a cause of pain }\end{array}$ \\
\hline
\end{tabular}




\begin{tabular}{|c|c|c|}
\hline & $\begin{array}{l}\text { term jointy does not provide detail } \\
\text { of the problem and its almost as } \\
\text { though she is unable to explain } \\
\text { further. Poor understanding of } \\
\text { complexities of pain? Rachel focus } \\
\text { of pain is related to source of } \\
\text { symptoms which are most often } \\
\text { anatomical structures. }\end{array}$ & $\begin{array}{l}\text { ? Lack of understanding of pain } \\
\text { complexity }\end{array}$ \\
\hline $\begin{array}{l}\text { So just kind of look at } \\
\text { sources of pain um and } \\
\text { then every session you } \\
\text { kind of go 'how's your } \\
\text { pain?' } \\
\text { INT: mm.. }\end{array}$ & $\begin{array}{l}\text { The pain discussion seems to be } \\
\text { limited by asking how the pain is } \\
\text { and checking the sources of } \\
\text { symptoms. (Structures) } \\
\text { Little emphasis on pain education } \\
\text { more focus on movement and } \\
\text { structures. }\end{array}$ & $\begin{array}{l}\text { Pain education as highlighting } \\
\text { sources of pain }\end{array}$ \\
\hline $\begin{array}{l}\text { Rachel: Um, and they'll } \\
\text { go 'aw yeah, feel a bit } \\
\text { better today.' Or 'I get } \\
\text { my pain here.' And you } \\
\text { know just talk about pain } \\
\text { not necessarily being a } \\
\text { bad thing, sometimes it } \\
\text { can be a que that you } \\
\text { have over done it. }\end{array}$ & $\begin{array}{l}\text { Rachel indicates she reassures the } \\
\text { patient that pain is not necessarily a } \\
\text { bad thing. And infers that it can just } \\
\text { be because someone has overdone } \\
\text { it which would suggest there is a } \\
\text { reaction to activity? Pain related to } \\
\text { activity }\end{array}$ & $\begin{array}{l}\text { Pain education as reassurance } \\
\text { that pain isn't bad }\end{array}$ \\
\hline $\begin{array}{l}\text { Or like l'll say to them, } \\
\text { you know if you're doing } \\
\text { the squats did you get } \\
\text { pain that time? And he'll } \\
\text { go no, and I'll say it's } \\
\text { because you know } \\
\text { you've been moving a lot } \\
\text { better. }\end{array}$ & $\begin{array}{l}\text { Rachel repeats that pain may have } \\
\text { reduced due to better movement. }\end{array}$ & $\begin{array}{l}\text { Pain education as highlighting } \\
\text { correlation between good } \\
\text { movement and pain }\end{array}$ \\
\hline $\begin{array}{l}\text { Or he'll say well I got pain } \\
\text { when I did this. So I might } \\
\text { then go and think about } \\
\text { checking that exercise } \\
\text { again. Checking that } \\
\text { they're doing that the } \\
\text { right way, um and then } \\
\text { seeing weather they got } \\
\text { pain from that. }\end{array}$ & $\begin{array}{l}\text { Rachel is keen to assess specific } \\
\text { activities causing the patient pain. It } \\
\text { seems the focus is exploring the } \\
\text { aggravating factors of pain and how } \\
\text { to modify them through improving } \\
\text { technique. }\end{array}$ & $\begin{array}{l}\text { Pain education as highlighting } \\
\text { correlation between good } \\
\text { movement and pain } \\
\text { Importance of assessment to } \\
\text { explore contributing pain factors } \\
\text { [movement dysfunction] }\end{array}$ \\
\hline $\begin{array}{l}\text { And you know, pain isn't } \\
\text { always a bad thing I'll say } \\
\text { to them. It's a warning } \\
\text { sign that maybe you're } \\
\text { not doing something } \\
\text { right in that case. }\end{array}$ & $\begin{array}{l}\text { Again, Rachel reassures patient that } \\
\text { pain is not always bad however } \\
\text { directly relates back to quality of a } \\
\text { movement/task. }\end{array}$ & $\begin{array}{l}\text { Pain education reassuring } \\
\text { patients' that pain is not always } \\
\text { bad } \\
\text { Pain education as explaining pain } \\
\text { is due to poor technique }\end{array}$ \\
\hline $\begin{array}{l}\text { INT: Nice, brilliant. } \\
\text { Rachel: Ok. }\end{array}$ & Interviewer thanks Rachel for input & \\
\hline
\end{tabular}




\begin{tabular}{|c|c|c|}
\hline $\begin{array}{l}\text { INT: Um and then just } \\
\text { finally, do you have one } \\
\text { more example you can } \\
\text { think of? } \\
\text { Rachel: Even though I say } \\
\text { the same stuff? }\end{array}$ & $\begin{array}{l}\text { Interviewer asks if Rachel has } \\
\text { another example and Rachel is } \\
\text { demonstrating she thinks she's } \\
\text { saying the same stuff. } \\
\text { Similar/generic approach to NSLBP? }\end{array}$ & $\begin{array}{l}\text { Similar/generic approach to } \\
\text { NSLBP? }\end{array}$ \\
\hline $\begin{array}{l}\text { INT: Yeah, its surprising } \\
\text { how different it is when } \\
\text { you really look at it in } \\
\text { detail. Just take your } \\
\text { time there is no rush. } \\
\text { Rachel: I've had a lot of } \\
\text { sporty knees in. mmm } \\
\text { I've had lots of necks in } \\
\text { recently. }\end{array}$ & $\begin{array}{l}\text { Interviewers explains how there are } \\
\text { differences when the data is looked } \\
\text { at in detail. Rachel thinks of another } \\
\text { case to discuss. }\end{array}$ & $\begin{array}{l}\text { Similar approach to pain } \\
\text { education for each patient (with } \\
\text { NSLBP?) }\end{array}$ \\
\hline $\begin{array}{l}\text { I had one guy, he wasn't } \\
\text { really non-specific, he } \\
\text { was like getting in and } \\
\text { out of the tanks. It was } \\
\text { more of a facet joint } \\
\text { problem because he was } \\
\text { extending his back. }\end{array}$ & $\begin{array}{l}\text { Rachel thinks of a patient however } \\
\text { unsure if it's appropriate as the } \\
\text { patient had a "facet problem." Poor } \\
\text { understanding of NSLBP as facet } \\
\text { issue would still be NSLBP. Another } \\
\text { clear structural issue (facet } \\
\text { problem). }\end{array}$ & $\begin{array}{l}\text { Assumption of physiotherapist's } \\
\text { poor understanding of NSLBP }\end{array}$ \\
\hline $\begin{array}{l}\text { INT: That's ok. } \\
\text { Rachel: Is that alright? } \\
\text { INT: Yeah, yeah. On x-ray } \\
\text { you might not necessarily } \\
\text { see.. }\end{array}$ & $\begin{array}{l}\text { Interviewer reassures Rachel that } \\
\text { the case would be appropriate to } \\
\text { discuss. }\end{array}$ & \\
\hline $\begin{array}{l}\text { Rachel: Yeah. Um, so } \\
\text { youngish guy. So at work, } \\
\text { they've got to um, they } \\
\text { do the wings basically. } \\
\text { They have to get inside } \\
\text { the wing and then do all } \\
\text { the nuts and bolts. Um, } \\
\text { and there's a perquisite } \\
\text { so it's like a big, like a } \\
\text { circle, like that so before } \\
\text { they get the job they've } \\
\text { got to fit in the circle ok. } \\
\text { INT: Wow. }\end{array}$ & $\begin{array}{l}\text { Rachel explains what the patient } \\
\text { does for work. }\end{array}$ & \\
\hline $\begin{array}{l}\text { Rachel: Cus that's the } \\
\text { side of the wing when } \\
\text { they get in. And they } \\
\text { have to get in at all } \\
\text { different angles. Um and } \\
\text { they're in there for quite } \\
\text { a good period of time. So } \\
\text { this guy had to get in sort } \\
\text { of like, he was getting like } \\
\text { that and going under like } \\
\text { this. And he wasn't a }\end{array}$ & $\begin{array}{l}\text { Rachel further demonstrates some } \\
\text { of the positions the patient has to } \\
\text { get in at work. Is she already } \\
\text { thinking that these movements are } \\
\text { causing pain? }\end{array}$ & Movements causing pain. \\
\hline
\end{tabular}




\begin{tabular}{|c|c|c|}
\hline $\begin{array}{l}\text { small guy, he wasn't fat } \\
\text { but he was quite a } \\
\text { chunky rugby type guy. } \\
\text { INT: Yeah. }\end{array}$ & & \\
\hline $\begin{array}{l}\text { Rachel: He obviously } \\
\text { fitted through the circle } \\
\text { but it was the way he was } \\
\text { getting in. }\end{array}$ & $\begin{array}{l}\text { Rachel states that it was the way } \\
\text { the patient was getting into the } \\
\text { circle which was causing the issue. }\end{array}$ & $\begin{array}{l}\text { Physiotherapist beliefs that } \\
\text { movement is causing pain }\end{array}$ \\
\hline $\begin{array}{l}\text { And he was just getting } \\
\text { really sort of bad sort of } \\
\text { um lower back pain, right } \\
\text { and left depending on } \\
\text { which side he was getting } \\
\text { or which leg was going in. }\end{array}$ & $\begin{array}{l}\text { It seems as though Rachel has a } \\
\text { mechanical way of thinking } \\
\text { highlighting that a certain side } \\
\text { would hurt during the task. This } \\
\text { seems very specific and maybe not } \\
\text { something the patient would have } \\
\text { highlighted? }\end{array}$ & $\begin{array}{l}\text { Physiotherapist beliefs that } \\
\text { movements is causing pain }\end{array}$ \\
\hline $\begin{array}{l}\text { Um, so he was like aw } \\
\text { you know 'what's wrong } \\
\text { with my back?' And I was } \\
\text { like you know prodding } \\
\text { and pressing some glute } \\
\text { trigger points, a little bit } \\
\text { of joint pain um, it's kind } \\
\text { of a multitude of things } \\
\text { that would cause his } \\
\text { pain. }\end{array}$ & $\begin{array}{l}\text { Rachel explains that she was doing } \\
\text { a 'hands on' assessment. Unable to } \\
\text { specify structure think there may be } \\
\text { a number of things causing pain }\end{array}$ & $\begin{array}{l}\text { Pain education as explaining } \\
\text { [mechanical] cause of pain }\end{array}$ \\
\hline $\begin{array}{l}\text { Um, so I just said look 'its } \\
\text { more to do with, you } \\
\text { could be irritating the } \\
\text { facet joints, and } \\
\text { obviously muscles you're } \\
\text { just pinching.' }\end{array}$ & $\begin{array}{l}\text { Rachel specifies that the patient } \\
\text { could be irritating facet joints. Again } \\
\text { this is structural issue. And states } \\
\text { that muscles are "obviously" } \\
\text { pinching. Terminology like 'just' is } \\
\text { used, does this infer that this is a } \\
\text { pattern that is always seen? }\end{array}$ & $\begin{array}{l}\text { Pain education as explaining } \\
\text { [mechanical] cause of NSLBP }\end{array}$ \\
\hline $\begin{array}{l}\text { And he was already in } \\
\text { like a, an anterior tilt } \\
\text { anyway. So he was going } \\
\text { even further as he was } \\
\text { stepping backwards in. }\end{array}$ & $\begin{array}{l}\text { Again Rachel explains that the } \\
\text { patient was already in "an anterior } \\
\text { tilt." Is Rachel automatically drawn } \\
\text { to the cause of pain because of } \\
\text { posture. }\end{array}$ & $\begin{array}{l}\text { Postural/mechanical position } \\
\text { causing pain } \\
\text { Anterior tilt = pain }\end{array}$ \\
\hline $\begin{array}{l}\text { Um, so I sort of said its } \\
\text { more to do with what } \\
\text { you are doing. }\end{array}$ & $\begin{array}{l}\text { Rachel Relates it to patient's activity } \\
\text { - blame on patient? }\end{array}$ & $\begin{array}{l}\text { Pain education as highlighting } \\
\text { lifestyle (mechanical factors) } \\
\text { causing pain }\end{array}$ \\
\hline $\begin{array}{l}\text { We narrowed it down, } \\
\text { like what was causing his } \\
\text { pain, and he was like I } \\
\text { was getting in and out of } \\
\text { the tank. }\end{array}$ & $\begin{array}{l}\text { Rachel stated that it was the activity } \\
\text { of getting in and out of the tank } \\
\text { causing pain. It seems as though } \\
\text { this was collaboratively identified } \\
\text { ("we narrowed it down".) }\end{array}$ & $\begin{array}{l}\text { Pain education as highlighting } \\
\text { lifestyle (mechanical factors) } \\
\text { causing pain }\end{array}$ \\
\hline
\end{tabular}




\begin{tabular}{|c|c|c|}
\hline $\begin{array}{l}\text { Umm, but he was quite } \\
\text { concerned because his } \\
\text { pain wasn't settling and } \\
\text { he was like 'do I need an } \\
\text { x-ray? Do I need a scan?' }\end{array}$ & $\begin{array}{l}\text { Patient expresses concern for pain } \\
\text { and considers if he requires } \\
\text { imaging? }\end{array}$ & $\begin{array}{l}\text { Patient considering use of } \\
\text { imaging }\end{array}$ \\
\hline $\begin{array}{l}\text { I was like no because } \\
\text { there was no real you } \\
\text { know no red flags or } \\
\text { anything like that, he was } \\
\text { fit and healthy. And I was } \\
\text { like it's how you're } \\
\text { getting in and out of the } \\
\text { tank basically. } \\
\text { INT: mm.. }\end{array}$ & $\begin{array}{l}\text { Rachel assured patient that imaging } \\
\text { not required and linked pain back to } \\
\text { an activity. }\end{array}$ & $\begin{array}{l}\text { Pain education as reassuring } \\
\text { patient that imaging not always } \\
\text { required } \\
\text { Pain education as highlighting } \\
\text { lifestyle (mechanical factors) } \\
\text { causing pain }\end{array}$ \\
\hline $\begin{array}{l}\text { Rachel: Um, so we did } \\
\text { like the movement } \\
\text { control test, so and I } \\
\text { explained to him, you } \\
\text { know this is looking at } \\
\text { how you move through } \\
\text { your pelvis. Every time } \\
\text { you get into the tank } \\
\text { you're arching your back. } \\
\text { INT: mm.. }\end{array}$ & $\begin{array}{l}\text { Rachel utilised the 'movement } \\
\text { control test again' and explained to } \\
\text { the patient that he is arching his } \\
\text { back every time he enters the tank. } \\
\text { Rachel has clear relationship } \\
\text { between movement/posture as an } \\
\text { issue. It is portrayed as a basic issue. }\end{array}$ & $\begin{array}{l}\text { Movement control assessment } \\
\text { to inform contributing pain } \\
\text { factors [to inform subsequent } \\
\text { pain education] }\end{array}$ \\
\hline $\begin{array}{l}\text { Rachel: And he was like } \\
\text { what does that mean? So } \\
\text { we did the test, the PBU, } \\
\text { and that was quite good } \\
\text { cus he could see the } \\
\text { pressure, and he could } \\
\text { see when he was in } \\
\text { arching his back. }\end{array}$ & $\begin{array}{l}\text { Rachel used the PBU to provide the } \\
\text { patient with visual feedback. } \\
\text { Patient unaware what Rachel } \\
\text { meant regarding the arching of back }\end{array}$ & $\begin{array}{l}\text { Patient lacks understanding of } \\
\text { problem } \\
\text { Use of visual feedback during } \\
\text { assessment to improve patient } \\
\text { understanding of pain } \\
\text { contributing factors }\end{array}$ \\
\hline $\begin{array}{l}\text { I was like you can put } \\
\text { your hand underneath } \\
\text { there and he was like aw } \\
\text { ok. I was like when you } \\
\text { flatten your back, you } \\
\text { can't put a hand there. So } \\
\text { you know, if you arch } \\
\text { you've got a massive } \\
\text { space in that back. He } \\
\text { was like aw ok. }\end{array}$ & $\begin{array}{l}\text { Rachel encourages patient to put } \\
\text { hands underneath back to improve } \\
\text { understanding of exercise. } \\
\text { More focus on arching of back, is } \\
\text { this an issue? }\end{array}$ & Focus on arching of back \\
\hline $\begin{array}{l}\text { So and his core, like his } \\
\text { control was pretty poor } \\
\text { really. }\end{array}$ & $\begin{array}{l}\text { Patient had poor core control. } \\
\text { Focus of assessment seems to be } \\
\text { posture and core stability. }\end{array}$ & $\begin{array}{l}\text { Poor core control contributing to } \\
\text { NSLBP }\end{array}$ \\
\hline $\begin{array}{l}\text { Um, so then we did those } \\
\text { tests explain what was } \\
\text { happening with the back. }\end{array}$ & $\begin{array}{l}\text { Use of tests to explain mechanics of } \\
\text { back }\end{array}$ & $\begin{array}{l}\text { Importance of assessment to } \\
\text { explain movement based pain } \\
\text { contributing factors }\end{array}$ \\
\hline
\end{tabular}




\begin{tabular}{|c|c|c|}
\hline $\begin{array}{l}\text { And then we looked at } \\
\text { doing it in a standing } \\
\text { position because it was, } \\
\text { he was taking the leg } \\
\text { back and going into the } \\
\text { tank. }\end{array}$ & $\begin{array}{l}\text { Rachel attempts to make } \\
\text { assessment more specific to } \\
\text { patient's occupation. }\end{array}$ & $\begin{array}{l}\text { Individualised assessment } \\
\text { relevant for the patient }\end{array}$ \\
\hline $\begin{array}{l}\text { So um, I think I did an } \\
\text { exercise where he was } \\
\text { standing up against the } \\
\text { wall, you need to just } \\
\text { bring his feet about a } \\
\text { foot length away from } \\
\text { the wall, slide down, and } \\
\text { then his back was } \\
\text { arching. I was like can } \\
\text { you put a hand behind } \\
\text { your back he was like } \\
\text { yeah, I was like alright } \\
\text { well flatten your back, } \\
\text { and I said, that's then } \\
\text { your back's kind of in a } \\
\text { neutral or it's not } \\
\text { arching. He was like ok, I } \\
\text { was like slide down the } \\
\text { wall, keep your back flat } \\
\text { against the wall. So we } \\
\text { drilled that a few times. }\end{array}$ & $\begin{array}{l}\text { Rachel explains the exercise in } \\
\text { standing. Exercise is focused on the } \\
\text { arching of the back. }\end{array}$ & Mechanical/postural focus \\
\hline $\begin{array}{l}\text { And then we did another } \\
\text { exercise where he was } \\
\text { standing up against the } \\
\text { wall, standing there like } \\
\text { that. Part of your back } \\
\text { there. And then I was like } \\
\text { right take the leg behind } \\
\text { you, but don't arch your } \\
\text { back. }\end{array}$ & $\begin{array}{l}\text { Focus on arching of back is this } \\
\text { because it causes pain }\end{array}$ & Mechanical/postural focus \\
\hline $\begin{array}{l}\text { Ok so, every time you } \\
\text { step into the tank, you're } \\
\text { going to move the leg but } \\
\text { not the back. }\end{array}$ & $\begin{array}{l}\text { Rachel commands patient to step } \\
\text { into tank in a certain way. It seems } \\
\text { Rachel thinks that a simple change } \\
\text { in mechanics would reduce NSLBP? }\end{array}$ & $\begin{array}{l}\text { Mechanical changes to improve } \\
\text { NSLBP }\end{array}$ \\
\hline $\begin{array}{l}\text { Ok, so we used that as an } \\
\text { exercise. Um and so a lot } \\
\text { more of hip extension } \\
\text { type exercises without } \\
\text { moving the back for him. }\end{array}$ & $\begin{array}{l}\text { Rachel transferred assessment in to } \\
\text { exercise which helps with } \\
\text { specificity. Exercise to focus on not } \\
\text { moving the back. }\end{array}$ & $\begin{array}{l}\text { Assessment informs treatment } \\
\text { Exercise focus on mechanics }\end{array}$ \\
\hline $\begin{array}{l}\text { Um, and he was like aw I } \\
\text { may not get into the tank } \\
\text { that way. So then we } \\
\text { looked, I think we still } \\
\text { kept doing those type of } \\
\text { exercises. }\end{array}$ & $\begin{array}{l}\text { Patient stated he may not get into } \\
\text { the tank how he was asked }\end{array}$ & $\begin{array}{l}\text { Disagreement between patient } \\
\text { and physiotherapist. }\end{array}$ \\
\hline
\end{tabular}




\begin{tabular}{|c|c|c|}
\hline $\begin{array}{l}\text { We did four-point } \\
\text { kneeling, um where cus } \\
\text { he was rotating and } \\
\text { extending the back every } \\
\text { time. }\end{array}$ & Explanation of another exercise. & \\
\hline \multicolumn{3}{|l|}{$\begin{array}{l}\text { INT: Ok. } \\
\text { Rachel: So we worked a } \\
\text { lot on rotation and } \\
\text { extension. } \\
\text { INT: Yeah. }\end{array}$} \\
\hline \multicolumn{3}{|l|}{$\begin{array}{l}\text { Rachel: Um which to him } \\
\text { was arching the back. }\end{array}$} \\
\hline $\begin{array}{l}\text { Um and yeah his back } \\
\text { pain got better. }\end{array}$ & Patients pain improved. & \\
\hline $\begin{array}{l}\text { He kind of reduced some } \\
\text { of the hours that he was } \\
\text { doing um, so I think that } \\
\text { helped a little bit. And he } \\
\text { said 'aw I'm just going to } \\
\text { change how I get into the } \\
\text { tank.' }\end{array}$ & $\begin{array}{l}\text { The conversation is summarised by } \\
\text { Rachel explaining that a slight } \\
\text { reduction in hours of work and } \\
\text { change in how patients gets in and } \\
\text { out of tank resulted in reduction of } \\
\text { pain. Rachel seems to present a } \\
\text { simplistic view of assessment and } \\
\text { treatment of NSLBP which is } \\
\text { focused primarily on movement, } \\
\text { anatomy and mechanical issues of } \\
\text { the back. }\end{array}$ & $\begin{array}{l}\text { Patient's pain improves } \\
\text { Change in movement improved } \\
\text { NSLBP } \\
\text { Reduction of work hours } \\
\text { contributing to improvement in } \\
\text { NSLB. }\end{array}$ \\
\hline $\begin{array}{l}\text { INT: Brilliant, fantastic, } \\
\text { thank you very much. }\end{array}$ & & \\
\hline
\end{tabular}




\section{Appendix 2}

Figures 1 and 2 demonstrate the process of grouping the emergent themes with the superordinate themes listed above the emergent themes (the numbers in the pictures assisted the author with organisation during the process, they have no significant value to the analysis process). Figure 1 simply illustrates the process (one participant example) of grouping emergent themes to super-ordinate themes.

Figure 1. Grouping emergent themes into super-ordinate themes:

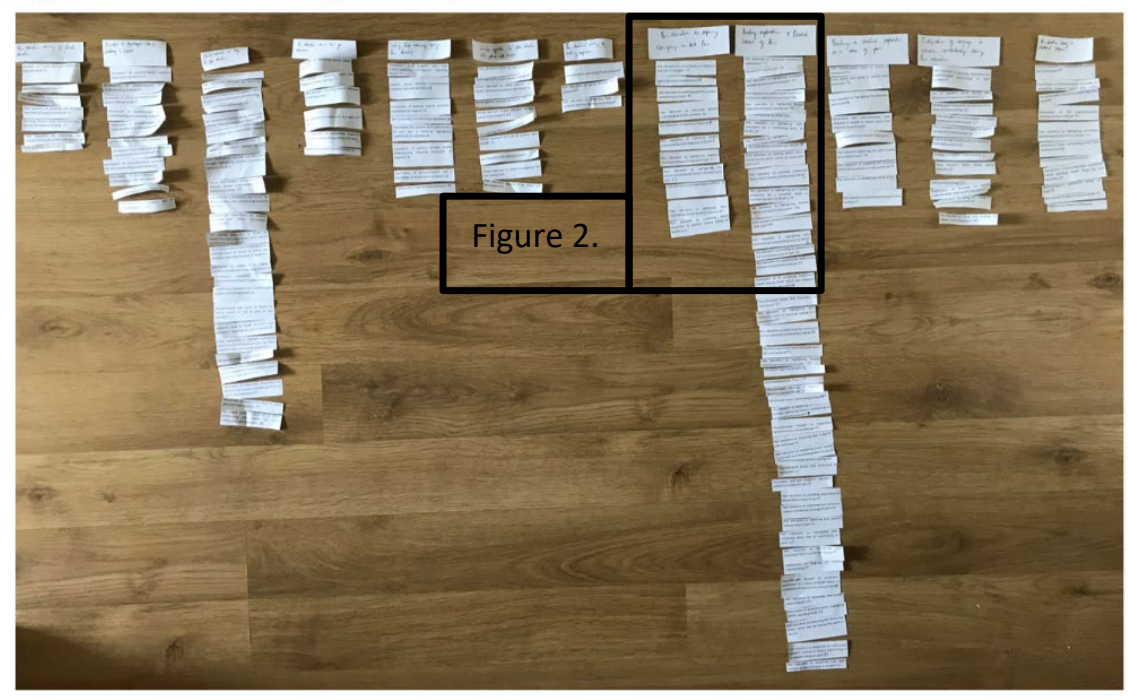

Figure 2. Excerpt from figure 1:

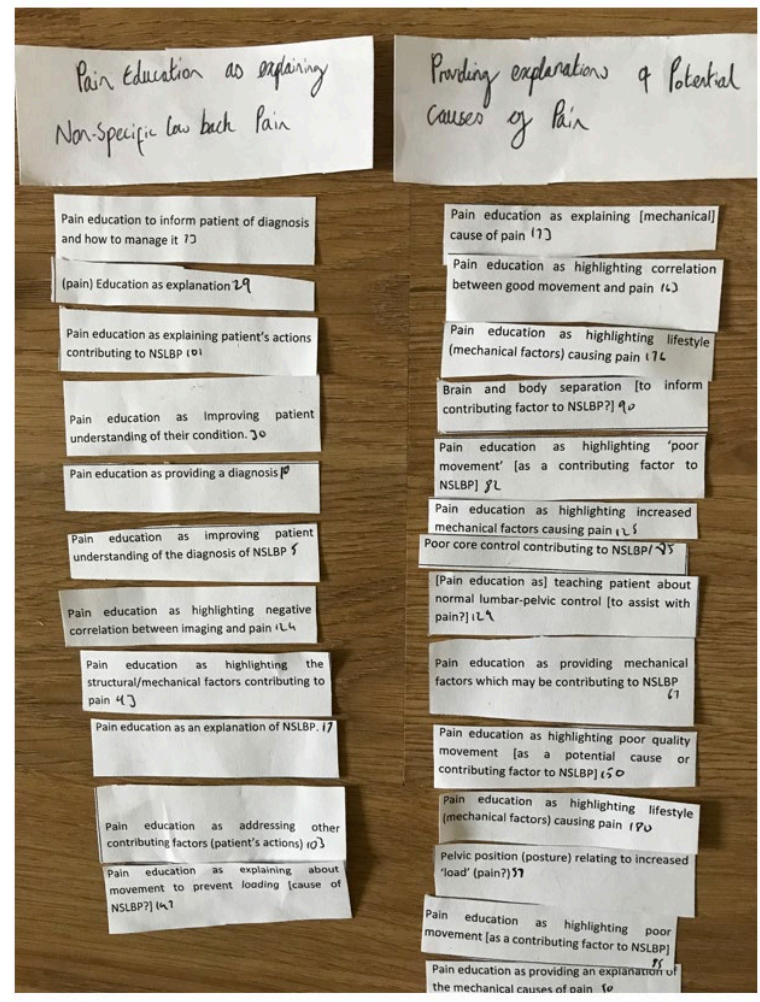




\section{Appendix 3}

\section{Development of Master Themes from Super-Ordinate Themes (Across all 6 Interviews)}

\begin{tabular}{|c|c|}
\hline Master Themes & Super-ordinate Themes \\
\hline \multirow{6}{*}{$\frac{\text { Theme 1: Experienced significance of assessment in }}{\text { understanding NSLBP }}$} & $\begin{array}{l}\text { Importance of subjective assessment in pain } \\
\text { education (Linda) }\end{array}$ \\
\hline & $\begin{array}{l}\text { Assessment is significant to pain education } \\
\text { (Paula) }\end{array}$ \\
\hline & Assessment as key to pain education (Jessica) \\
\hline & $\begin{array}{l}\begin{array}{l}\text { Assessment facilitates pain education } \\
\text { (Sophie) }\end{array} \\
\text { (Soln }\end{array}$ \\
\hline & $\begin{array}{l}\text { Pain education facilitated by assessment } \\
\text { (Bethan) }\end{array}$ \\
\hline & $\begin{array}{l}\text { Initial assessment as key in pain education } \\
\text { (Rachel) }\end{array}$ \\
\hline \multirow{12}{*}{ Theme 2: PE as explaining the nature of NSLBP } & $\begin{array}{l}\text { Explaining mechanical causes of NSLBP } \\
\text { (Linda) }\end{array}$ \\
\hline & $\begin{array}{l}\text { Explaining non-mechanical causes to NSLBP } \\
\text { (Linda) }\end{array}$ \\
\hline & $\begin{array}{l}\text { Pain education as explaining causes of pain } \\
\text { (Paula) }\end{array}$ \\
\hline & Explaining causes of pain (Jessica) \\
\hline & Pain education as explaining pain (Jessica) \\
\hline & $\begin{array}{l}\text { Pain education explaining the difference } \\
\text { between chronic and acute NSLBP (Sophie) }\end{array}$ \\
\hline & $\begin{array}{l}\text { Pain education to explain pain causes } \\
\text { (Sophie) }\end{array}$ \\
\hline & Pain education as explaining cause (Bethan) \\
\hline & $\begin{array}{l}\text { Pain education as anatomy explanation } \\
\text { (Rachel) }\end{array}$ \\
\hline & $\begin{array}{l}\text { Pain education as explaining causes of pain } \\
\text { (Rachel) }\end{array}$ \\
\hline & Pain education as explaining NSLBP (Rachel) \\
\hline & Structural explanations of NSLBP (Rachel) \\
\hline \multirow{10}{*}{ Theme 3: Experienced challenges in providing PE } & Difficulty providing pain education (Linda) \\
\hline & $\begin{array}{l}\text { Reduced effectiveness of pain education } \\
\text { (Linda) }\end{array}$ \\
\hline & $\begin{array}{l}\text { Physiotherapists lack of understanding } \\
\text { regarding pain education (Paula) }\end{array}$ \\
\hline & Difficulty providing pain education (Paula) \\
\hline & Pain education difficult to provide (Jessica) \\
\hline & Pain education as lacking detail (Paula) \\
\hline & $\begin{array}{l}\text { NSLBP patients- can cause frustration for } \\
\text { physiotherapist when working (Jessica) }\end{array}$ \\
\hline & $\begin{array}{l}\text { Patient difficulty understanding pain } \\
\text { education (Sophie) }\end{array}$ \\
\hline & Barriers to pain education (Bethan) \\
\hline & $\begin{array}{l}\text { Physiotherapists lack of NSLBP } \\
\text { understanding (Rachel) }\end{array}$ \\
\hline
\end{tabular}




\begin{tabular}{|c|c|}
\hline \multirow{10}{*}{ Theme 4: Individualisation as key to PE for NSLBP } & CPD assisting pain education (Linda) \\
\hline & $\begin{array}{l}\text { Pain education varying between HCP's } \\
\text { (Linda) }\end{array}$ \\
\hline & Skills required for pain education (Paula) \\
\hline & CPD assists Pain education (Paula) \\
\hline & Individualising pain education (Paula) \\
\hline & $\begin{array}{l}\text { Pain education varying in different settings } \\
\text { (Sophie) }\end{array}$ \\
\hline & Individualising pain education (Sophie) \\
\hline & $\begin{array}{l}\text { Importance of communication skills for pain } \\
\text { education (Sophie) }\end{array}$ \\
\hline & $\begin{array}{l}\text { Physiotherapist attributes and the } \\
\text { therapeutic relationship as vital for pain } \\
\text { education (Bethan) }\end{array}$ \\
\hline & $\begin{array}{l}\text { Modifying language to increase patient } \\
\text { understanding of pain education (Rachel) }\end{array}$ \\
\hline \multirow{10}{*}{$\begin{array}{c}\text { Theme 5: Reassurance as central to PE for people } \\
\text { living with NSLBP }\end{array}$} & Pain education to reassure (Linda) \\
\hline & Dispelling myths and negative beliefs (Paula) \\
\hline & Pain education to empower patient (Paula) \\
\hline & $\begin{array}{l}\text { Pain education as reassuring patients } \\
\text { (Jessica) }\end{array}$ \\
\hline & $\begin{array}{l}\text { Pain education with movement, reassures } \\
\text { patients (Paula) }\end{array}$ \\
\hline & $\begin{array}{l}\text { Pain education changing patient beliefs } \\
\text { (Sophie) }\end{array}$ \\
\hline & $\begin{array}{l}\text { Pain education to empower patient and } \\
\text { encourage self-management (Sophie) }\end{array}$ \\
\hline & $\begin{array}{l}\text { Pain education offering encouragement and } \\
\text { reassurance (Bethan) }\end{array}$ \\
\hline & $\begin{array}{l}\text { Pain education facilitating independence } \\
\text { (Bethan) }\end{array}$ \\
\hline & Pain education as reassuring (Rachel) \\
\hline
\end{tabular}

